Research, part of a Special Feature on Adaptation in Fire-Prone Landscapes: Interactions of Policies, Management. Wildfire, and Social Networks in Oregon, USA

\title{
Spatiotemporal dynamics of simulated wildfire, forest management, and forest succession in central Oregon, USA
}

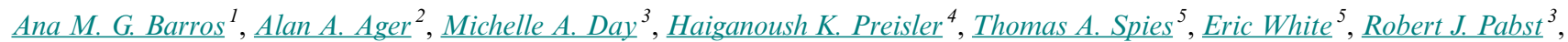

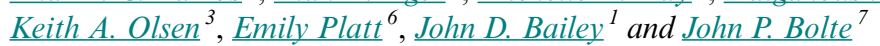

\begin{abstract}
We use the simulation model Envision to analyze long-term wildfire dynamics and the effects of different fuel management scenarios in central Oregon, USA. We simulated a 50-year future where fuel management activities were increased by doubling and tripling the current area treated while retaining existing treatment strategies in terms of spatial distribution and treatment type. We modeled forest succession using a state-and-transition approach and simulated wildfires based on the contemporary fire regime of the region. We tested for the presence of temporal trends and overall differences in burned area among four fuel management scenarios. Results showed that when the forest was managed to reduce fuels it burned less: over the course of 50 years there was up to a $40 \%$ reduction in area burned. However, simulation outputs did not reveal the expected temporal trend, i.e., area burned did not decrease progressively with time, nor did the absence of management lead to its increase. These results can be explained as the consequence of an existing wildfire deficit and vegetation succession paths that led to closed canopy, and heavy fuels forest types that are unlikely to burn under average fire weather. Fire (and management) remained relatively rare disturbances and, given our assumptions, were unable to alter long-term vegetation patterns and consequently unable to alter long-term wildfire dynamics. Doubling and tripling current management targets were effective in the near term but not sustainable through time because of a scarcity of stands eligible to treat according to the modeled management constraints. These results provide new insights into the long-term dynamics between fuel management programs and wildfire and demonstrate that treatment prioritization strategies have limited effect on fire activity if they are too narrowly focused on particular forest conditions.
\end{abstract}

Key Words: agent-based model; Deschutes National Forest; Flammap; minimum travel time; state-and-transition model

\section{INTRODUCTION}

Over the past three decades the western U.S. observed a sharp increase in number of fires, burned area, and length of the fire season in contrast to the low fire activity during most of the middle to late 20th century (Littell et al. 2009, Jolly et al. 2015, Westerling 2016). Previous studies have shown evidence of coupling between the recent increase in fire activity and climate (Littell et al. 2009, Marlon et al. 2012, Abatzoglou and Kolden 2013, Westerling 2016); however, for the Pacific Northwest (PNW) region longterm historical records of biomass burning suggest that climate alone cannot explain the temporal variation in area burned (Heyerdahl et al. 2002, Hessl et al. 2004, Marlon et al. 2012). In the absence of strong climatic controls on fire activity, a common explanation for burned area fluctuations through time is humaninduced land cover changes. Heyerdahl et al. (2002) interpreted the reduction in burned area during the early decades of the 20th century as the consequence of low, sparse fuels due to the increase in the number of domestic livestock during the European settlement. This period was followed by a strong fire suppression policy in the late 1930s that excluded fire on fire-adapted landscapes, a policy still in effect today. Thus, the recent increase in fire activity in the PNW is the likely outcome of fuel accumulation resulting from human activities, combined with the beginning of a dry and warm period (Mote 2003, Brown et al. 2004, Westerling et al. 2006, Jolly et al. 2015) that is concurrent with the onset of climate change effects (Abatzoglou et al. 2014). Despite the increase in number of fires and burned area, contemporary trends of fire severity and how they compare with historical trends remains a subject of debate (Hessburg et al. 2005, 2007, Noss et al. 2006, Miller et al. 2009, Odion et al. 2014, 2016, Sherriff et al. 2014, Baker 2015, Stevens et al. 2016). Reduction of fire severity is one of the objectives of restoration programs (U.S. Congress 2003), but restoration goals may not be accomplished if that target is estimated against a biased historical baseline. Regardless of the relative role of high-severity fire in historical fire regimes of the western U.S., fire-excluded forests in the PNW have now comparatively higher fuel loads (Hessburg et al. 2005, Thompson and Spies 2009, Merschel et al. 2014). This means that holding all other factors constant, these forests are more likely to burn with high severity than in the past, even if they only burn under severe weather conditions (Weatherspoon et al. 1992). Moreover, under most modeling scenarios of future greenhouse emissions and projected climate impacts, the likelihood of severe fire weather is expected to increase, as is burned area and fire severity (Littell et al. 2009, Spracklen et al. 2009, Halofsky et al. 2014a, Stavros et al. 2014).

The increase in burned area over the past three decades (Westerling 2016) is especially apparent on western U.S. national forests where large fire-prone landscapes are juxtaposed with expanding wildland urban interfaces (WUI), and federal land management restricts fuel management in some areas to protect biodiversity and other amenities (Williams 2013, Ager et al. 2014a, North et al. 2015). The WUI expansion and increase in highly valued resources that are susceptible to fire have led to an increase in landscape wildfire risk.

\footnotetext{
${ }^{1}$ Oregon State University, College of Forestry, Department of Forest Engineering, Resources \& Management, ${ }^{2}$ USDA Forest Service, Rocky Mountain Research Station, Missoula Fire Sciences Laboratory, ${ }^{3}$ Oregon State University, College of Forestry, Department of Forest Ecosystems \& Society, ${ }_{4}^{4}$ USDA Forest Service, Pacific Southwest Research Station, ${ }^{5}$ USDA Forest Service, Pacific Northwest Research Station, ${ }^{6}$ United States Forest Service, Region 6, ${ }^{7}$ Oregon State University, College of Agricultural Sciences, Department of Biological \& Ecological Engineering
} 
This growing threat of wildfire losses has led to a number of new U.S. federal policies and expanded investments in forest and fuel management programs on both public and private lands. However, understanding the effectiveness of these programs on mitigating large, high-severity fires is difficult because wildfire spread is a complex and nonlinear spatial process that extends beyond the spatial scale of an individual stand (Peters et al. 2004, Slocum et al. 2010). Isolated stand-scale treatments may be effective when wildfires intersect them but, given the stochastic component of wildfire (ignition and spread), a significant proportion of the landscape has to be treated to be effective in reducing fire spread and fire behavior at the landscape scale (Agee and Skinner 2005). Scaling treatments from the stand to the landscape level has been the focus of many studies addressing various methods for spatially optimizing the arrangement of fuel treatments on the landscape to minimize spread rate and fire behavior (Finney 2001, 2007, Parisien et al. 2007, Schmidt et al. 2008), maximize habitat protection (Ager et al. 2010), and analyzing trade-offs in forest restoration programs (Vogler et al. 2015). However, relatively few studies have tackled the difficult and larger problem of long-term fuel management strategies. Incorporation of time in fuel management design is critical because treatments have a lifespan, which is determined by vegetation succession. Additionally, treatments are frequently completed on the same piece of ground over a sequence of years, highlighting the importance of modeling efforts that consider both the spatial and temporal dimensions of fuel treatment effects. A number of researchers have included temporal dynamics into simulation studies of spatiotemporal predictions of fire occurrence (Collins et al. 2011, Syphard et al. 2011), forest dynamics (Strom and Fulé 2007, Gustafson et al. 2010), and carbon sequestration (Loudermilk et al. 2014). Other simulation studies tested what-if scenarios that evaluated the economic efficiency of fuel treatments (Taylor et al. 2013) and anticipated the potential impacts of climate change on fire activity and forest composition (Scheller and Mladenoff 2005, Halofsky et al. 2014a, Yospin et al. 2015). Despite these studies, no clear patterns and conclusions can be made because of the widely different models, landscape conditions, calibrations, and assumptions about forest succession dynamics and fuel treatment effects.

In this study we use a newly developed version of Envision (Bolte et al. 2007), an agent-based landscape modeling system and the widely used minimum travel time fire spread algorithm (Finney 2002) to analyze long-term fuel management dynamics on a large multiownership landscape. This study is part of the "Forests, People, Fire" project that focused on the interactions, dynamics, and adaptations in coupled social and ecological systems in central Oregon (Spies et al. 2014). Spies et al. (2017) analyze the impact of alternative forest management policies on metrics that describe wildfire, forest structure, biodiversity, and timber production. In this paper we examine how alternative fuel management scenarios affect spatial and temporal patterns of wildfire. Specifically, we examined how different intensities of fuel management on federal lands compare in terms of (1) future burned area, and (2) future probability of an ignition generating a large fire. We hypothesized that without fuel reduction and under the contemporary pattern of ignitions and fire weather, burned area and the probability of large fires are expected to increase through the 50 years of simulation as a consequence of fuel accumulation. We support this hypothesis based on the observed increase in burned area in the PNW for the past three decades, which has been attributed to both climate and land cover changes leading to landscape homogeneity and higher fuel loads that favor wildfire progression (Perry et al. 2011, Hessburg et al. 2016, Westerling 2016). On the contrary, under active management directed at reducing fuel loads, burned area (and the probability of a large fire) should remain the same or decrease through time with higher reduction for scenarios with higher treatment intensity.

\section{METHODS}

\section{Study area}

The study area covers approximately 1.2 million ha of forest and range lands in the eastern Cascades of central Oregon, U.S. Vegetation types form a west to east gradient from alpine conifer forest in the higher elevations of the Cascades to moist mixedconifer forest, dry mixed conifer forest, lodgepole pine (Pinus contorta) and ponderosa pine (Pinus ponderosa) forests, western juniper (Juniperus occidentalis), and finally arid lands in the far east end of the study area (Fig. 1A). Moist mixed-conifer forests are mostly grand fir (Abies grandis), white fir (Abies concolor), Douglas-fir (Pseudotsuga menziesii), ponderosa pine and western larch (Larix occidentalis), while dry mixed conifer includes all of the abovementioned species in addition to lodgepole pine, Engelmann spruce (Picea engelmannii), incense cedar (Calocedrus decurrens), sugar pine (Pinus lambertiana), and western white pine (Pinus monticola). Nonvegetated areas, urban centers, water bodies, and roads account for $8 \%$ of the study area.

The study area includes lands managed by the United States Forest Service (USFS, 58\%, most of it corresponding to the Deschutes National Forest [DNF]), the Bureau of Land Management (BLM, 3\%), the Warm Springs Tribe (21\%), private forest corporations $(6 \%)$, and family forest landowners ( $4 \%)$. State lands include the Gilchrist State Forest and account for just 2\% of the landscape. Homeowners, who own tracts smaller than 2.5 ha, account for $7 \%$ of the study area (Fig. 1B).

Between 1992 and 2013, the study area had 372 ignitions per year ( $42 \%$ of caused by lightning, mostly during summer months) accounting for 11,423 ha burned per year (Short 2015). Recent large fires include the B\&B Complex in 2003 (36,733 ha), Pole Creek in 2012 (10,844 ha), and Sunnyside Turnoff in 2013 (21,448 ha).

\section{Envision overview}

We used Envision (Bolte et al. 2007) to model the interactions of forest management, succession, and wildfire at the landscape scale. Envision is a spatially explicit agent-based model that simulates major biophysical and social processes that drive landscape change (Fig. A1.1). Agents in Envision are landowners who have goals for the areas they manage and act on the landscape to achieve those goals. Agents' actions, which include forest and fuel management are constrained by forest policies and landscape condition. In this study, agents represented the major landowners in the study area: federal land managers, the Warm Springs Tribe, and private forest corporations. Envision also includes submodels that simulate autonomous landscape change processes: wildfire, forest succession, and population growth. These processes are agent-independent, but affect landscape condition and therefore 
Fig. 1. Maps of major vegetation management groups (A) and landowners (B) in the study area located in central Oregon, USA.
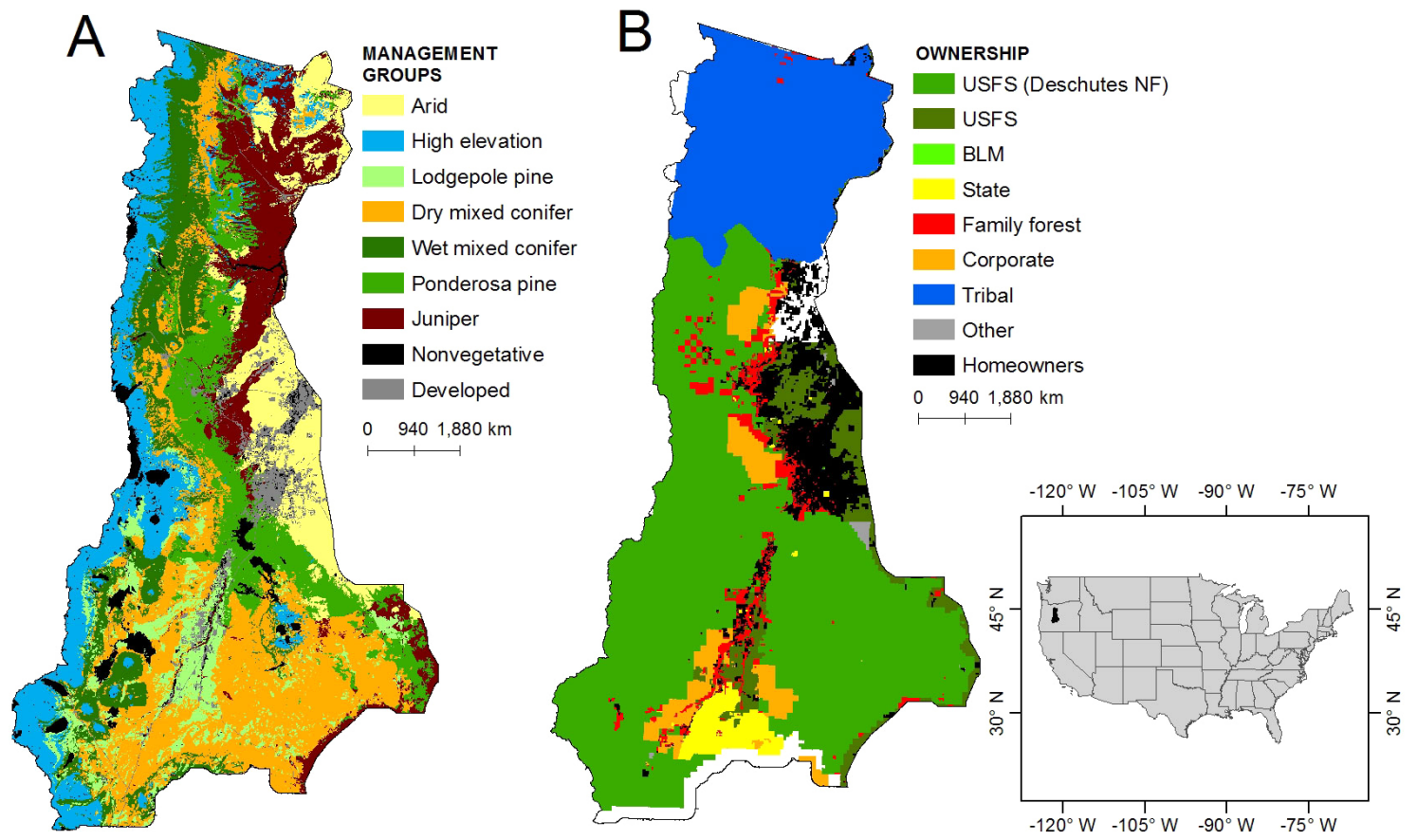

the ability for agents to meet their landscape goals through management activities.

Envision operates on a yearly time step and at the spatial scale of individual decision units (IDUs) ranging between 1 and 10 ha. Each IDU was uniquely characterized in terms of ecological and social attributes that described landscape condition and quantified resource production relevant to the different agents, e.g., timber production, biodiversity, burned area. In each time step, agents make decisions, the autonomous processes operate, and the ecological characteristics of an IDU vary as a consequence of wildfire, forest management, and vegetation succession. These changes are reflected in landscape condition and feedback into the following time step. We describe specific submodels of Envision as required for our particular study below.

\section{Vegetation succession}

Vegetation succession in Envision was simulated with existing state-and-transition simulation models (STSM) developed for all major upland vegetation types in Arizona, New Mexico, Oregon, and Washington under the Integrated Landscape Assessment Project (ILAP, Halofsky et al. 2014b). ILAP models were implemented in Envision using the Vegetation Dynamics Development Tool (VDDT) and expert opinion (Hemstrom et al. 2004, 2007). STSMs are empirical simulation models whereby vegetation is classified into a structural stage defined as a standardized combination of dominant cover type, diameter class, canopy cover, and forest layering. In Envision, changes in the vegetation state of an IDU were a function of succession rules and occurred both deterministically and probabilistically. Deterministic transitions occurred after a fixed amount of time had passed without disturbance and typically reflected age-based succession in STSM. Probabilistic transitions had an associated probability of occurrence, were age-independent, and resulted from parallel vegetation growth processes such as natural regeneration and understory development. Inclusion of probabilistic transitions in modeled vegetation succession allowed the generation of a distribution of projected outcomes for the state of each IDU. Probabilistic transitions can also be used to model disturbance processes such as insects, wildfire, or forest management. However, in this work changes in vegetation states due to disturbance followed a deterministic approach, implemented through the wildfire and forest management submodels. For further details on the forest succession model see Spies et al. (2017).

\section{Wildfire}

We built a wildfire submodel for Envision that combines a statistical fire forecasting model with the minimum travel time algorithm (MTT, Finney 2002) to simulate fire growth and model fire behavior. The wildfire submodel is summarized here and described in detail in Preisler et al. (2004), Preisler and Ager (2013), and Ager et al. (2014b). At each annual time step, a spatiotemporal ignition prediction model sampled a given number of ignitions as a function of location, day-of-year, and daily energy release component (ERC). This model was developed based on historical (1992-2009), spatial, and temporal fire ignition patterns and associated fire sizes. Weather conditions associated with each ignition were based on ERC value of the ignition day. Wind speed was sampled from the historical distribution (1992-2009, Lava Butte Remote Automated Weather Station, RAWS) of gust speed for days with area burned larger than 500 ha for any given ERC value. Wind direction was sampled from 
historical gust directions from the same Lave Butte RAWS data based on day-of-year. The MTT algorithm requires a burn period for each ignition that was based on an empirical relationship between burn period and fire size developed during the calibration process that is specific for the study area.

Wildfire outputs at the end of each time step (fire season) included simulated fire perimeters and predicted flame length for IDUs affected by fire. Wildfire severity was calculated at the IDU level by comparing modeled flame length with flame length thresholds that define surface fire, mixed-severity fire, and stand-replacing fire. These thresholds were derived from simulations with the Forest Vegetation Simulator (FVS; Dixon 2002) and the Fire and Fuels Extension (FFE). Specifically, tree lists were selected to represent each of the major vegetation states in the forest succession submodel and then simulated with FVS-FFE to determine the basal area mortality associated with flame lengths in $30-\mathrm{cm}$ intervals, up to $4.5 \mathrm{~m}$. Low severity (surface fire) corresponded with basal area mortality less than $20 \%$, mixed severity with $20-79 \%$ mortality, and high severity (stand-replacing fire) with $80 \%$ or greater tree mortality.

Fire effects were carried over to the next simulation time step through changes in the IDU forest and fuel structure. If any of the attributes of the IDU vegetation state, e.g., layering or canopy cover, changed as a consequence of fire, this would trigger a change in the IDU vegetation state. This was usually the case with stand-replacing fire. Fire modeling variables, canopy cover, and fuel model were updated to reflect the new, postfire vegetation state. However, a low-severity fire would reduce understory fuels without changing the IDU vegetation class. In these cases, only the IDU's fuel model was updated to reflect changes in the understory fuel structure. The postdisturbance fuel model persisted until a new disturbance took place or through 10 years, after which fuels returned to the predisturbance baseline (Tables A2.1 and A2.2). The timing of the transition to the predisturbance fuel model was based on expert opinion and in some cases informed by stand-level models (Hemstrom et al. 2004).

\section{Forest management allocator}

Forest management activities were simulated in Envision through a submodel that distributed treatments across the landscape based on a set of area targets, constraints, and preferences specific to each management action and actor (Table A3.1 and Table A3.2). Area targets defined the manager's objective in terms of maximum area treated annually and patch size. Constraints defined locations and conditions that could be selected for management and preference weights defined priorities within the selected locations. An example of a constraint was to restrict mechanical thinning to forested IDUs where diameter at breast height $>25$ $\mathrm{cm}$, and an example of a preference would be to prioritize treatments in the wildland-urban interface. Individual decision units (IDUs) that met the constraints were given a score based on their preference weights, then ranked and selected for treatment. The IDU with highest score was taken as the spatial kernel of a search algorithm that aggregated neighboring IDUs (that also met the constraints) and formed a treatment patch. The process of selecting kernel IDUs and expanding them into patches up to the maximum patch size was executed until the annual area target was met or the constraints inhibited further activity.

Similar to the wildfire submodel, the effects of treatment actions on an IDU's vegetation state depended on the predisturbance state and type of management action. If the treatment induced changes in the state descriptors, then it triggered a transition into a new vegetation state. For example, thinning that reduced the number of forest layers from multi to single triggered a new, posttreatment vegetation state. Management actions that only affected surface fuels, e.g., fuels mastication, led to changes in the fuel model that lasted for five years, after which the fuel model returned to the baseline predisturbance condition (Table A2.1 and Table A2.2).

On federal lands, forest management activities were allocated to areas designated for active management. These treatable areas were identified based on forest planning documents and discussions with federal forest managers on the DNF. Treatable area corresponded to approximately $54 \%$ of federal lands and excluded high elevation forests, congressionally designated wilderness areas, biodiversity reserves established to protect the Northern Spotted Owl (Strix occidentalis caurina), and other lands classified by the USFS as unsuitable because of steep slopes $(>30 \%$ ) and lack of roads (Fig. A4.1A). Forested land managed by other ownerships was considered treatable. Table 1 shows the management actions associated with each landowner. Constraints based on species and stand conditions, and preference weights used to select and rank eligible IDUs within the treatable area are shown in Table A3.1 and A3.2, respectively. Constraints and preference weights intended to simulate current management practices for each landowner and are based on the DNF land management plan (USFS 1990), information provided by federal managers and managers of other relevant ownerships in the study area.

\section{Simulation design}

We tested four management scenarios that modeled different area targets for fuel management on federal lands, i.e., management in tribal and corporate forests remains at current levels for all scenarios:

1. Current management: implements current area targets for federal, tribal, and corporate forests.

2. Double current management: doubles overall area treated per year under current management on federal lands (sum of area treated in all treatment actions).

3. Triple current management: triples overall area treated per year under current management on federal lands (sum of area treated in all treatment actions).

4. No management: implements no management on federal land and current levels of management on tribal and corporate forests.

With the exception of the no management scenario, all active management scenarios shared the same set of constraints and preferences, differing only in terms of their annual area targets. The annual area target was allocated as follows: $50 \%$ to mechanical thinning, 30\% to fuels mastication, and $20 \%$ to prescribed fire. Current management represented the status quo, corresponding to an annual target of $8500 \mathrm{ha}$, and to a treatment rate of $2.1 \%$ per year of treatable federal lands, the equivalent of $1.1 \%$ of all federal land and $0.7 \%$ of the study area. In the double and triple current management scenarios, annual area targets corresponded to $4.2 \%(17,000 \mathrm{ha})$ and $6.3 \%(25,500 \mathrm{ha})$ of treatable lands per year, respectively. 
Table 1. Forest and fuel management actions associated with each agent. Mechanical thinning removes $20 \%$ of stand volume while clear cut and partial harvest remove $100 \%$ and $75 \%$, respectively. Fuels mastication corresponds to mowing and grinding of surface fuels.

\begin{tabular}{lccccc}
\hline \hline Agent & $\begin{array}{c}\text { Mechanical } \\
\text { thinning }\end{array}$ & $\begin{array}{c}\text { Prescribed } \\
\text { fire }\end{array}$ & $\begin{array}{c}\text { Fuels } \\
\text { mastication }\end{array}$ & $\begin{array}{c}\text { Clear } \\
\text { cut }\end{array}$ & $\begin{array}{c}\text { Partial } \\
\text { harvest }\end{array}$ \\
\hline Federal & Yes & Yes & Yes & No & No \\
Warm Springs Tribe & Yes & Yes & No & Yes & No \\
Private forests & No & No & No & No & Yes \\
\hline
\end{tabular}

Initial vegetation states were identified from the gradient nearest neighborhood (GNN) dataset and based on year 2006 (Ohmann et al. 2011). Fuel models for the DNF were obtained from the DNF fuel model layer and in all other locations were based on fuel model mapping by LANDFIRE (Rollins 2009). The initial landscape was updated to 2012 to reflect disturbances and vegetation succession between 2006 and 2012 (Fig. A4.1B). Wildfires between 2006 and 2012 were updated using the Monitoring Trends in Burn Severity (MTBS) fire perimeter and fire severity classification tool (USFS and USGS 2009). Forest management was updated for the same period by implementing treatments on the landscape under the current management scenario (Fig. A4.1B).

We ran 15 replicates of 50 years each, based on empirical testing indicating that the percentage of burned area among landowners stabilizes around 15 replicates. Replicates represent alternative and equally probable fire scenarios that mimic historical variability in wildfire activity in the study area.

\section{Analysis of outputs}

\section{Burned area analysis}

We calculated average burned area and standard errors by fire severity class on federal forested lands, i.e., excluding arid lands and juniper areas. We fitted a linear model that uses year as the explanatory variable to determine the presence of a temporal linear trend in a time series of annual area burned. To compare overall burned area within scenarios we used a pairwise version of the Kruskal-Wallis nonparametric test (alpha $=0.05)$. The Kruskal-Wallis statistic was used to detect differences in overall burned area between all possible combinations of the management scenarios on federal lands, SILVIS WUI, wilderness, and old-growth areas. Wilderness areas and old-growth forest patches were defined according to the DNF land and resource management plan (USFS 1990) and SILVIS WUI was delineated based on the WUI definition in Radeloff et al. (2005). The SILVIS WUI is distinct from the federal WUI, which was used as a preference to prioritize mechanical treatments on federal land. The federal WUI layer is usually defined by local federal land managers based on boundaries described in local Community Wildfire Protection Plans (CWPPs). We chose to use SILVIS WUI to assess the impact of forest management in the WUI because of its wide acceptance by researchers, thorough documentation, and consistency throughout the U.S., which enables comparison with other studies. All analyses were done using MatLab R2015a (Mathworks 2015, http://www.mathworks.com).

Fire event analysis

We used fire size associated with individual fire perimeters to calculate the conditional probability, $p$, of a fire of a certain size class given an ignition. Probabilities for four distinct fire size classes $(>200 \mathrm{ha},>500 \mathrm{ha},>1000 \mathrm{ha}$, and > 10,000 ha) were estimated using logistic regression with ERC, burn period, wind speed, and management scenario as explanatory variables. Having the explanatory variables in the model enabled the comparison among treatment scenarios when all other variables in the model were kept the same. We also calculated the change in the odds $(p /[1-p])$ of a fire of a given size under the current, double, and triple current management scenarios, as compared with the odds of having the same fire under the no management scenario. All analyses were performed with R statistical software (R Core Team 2014).

\section{Treatment targets and treatment availability}

We reported the percentage of treatment target met in the study area in each simulation year. To quantify the temporal evolution of areas needing treatment, we calculated annual treatment availability as the area that meets the treatment allocation constraints at the end of each simulation year. Treatment availability describes the balance of disturbances and vegetation growth on the landscape. Each year, management and wildfires (depending on their location and severity) reduce the pool of area eligible for treatment, while vegetation succession adds new areas. Thus, treatment target reflects the amount of area that managers plan to treat annually, while treatment availability represents the amount of area in the landscape that could potentially be treated if resources were unlimited.

\section{RESULTS}

\section{Burned area analysis}

The majority $(70 \%)$ of wildfire in federal forested areas was classified as high-severity (stand-replacing) for all scenarios considered (Fig. A5.1), with considerable variability among simulation replicates for all fire severity classes (Fig. A5.2). Given the predominance of high-severity fire, all further results refer to area burned by stand-replacing fire. Mean burned area in forest lands showed no significant temporal trend (upward or downward) for any management scenario (Fig. 2 and associated parameters in Table A5.3). However, all active management scenarios were associated with lower burned area than under no management as indicated by overall burned area differences over the 50-year period (Table 2). On federal lands (Fig. 3A), and compared with no management, burned area in the 50 -year period was reduced by $25 \%, 36 \%$, and $40 \%$ for current, double, and triple management scenarios, respectively (Table 2 ). However, note that differences in burned area between current management and the increased management scenarios were not statistically significant (Table A5.4). Among land designations, old-growth areas showed the highest reduction in burned area because of management: 
reductions of $31 \%, 51 \%$, and $61 \%$ for current, double, and triple management scenarios, respectively (Fig. 3C, Table 2). This, however, was not the case for wilderness (Fig. 3B) or SILVIS WUI (Fig. 3D), where only very small differences were found in burned area between no management and any of the active management scenarios (Table 2).

Fig. 2. Plot of mean annual area burned by stand-replacing fire on all federal forest lands. Data points are averages over all 15 simulation replicates for current (CM), double current (DM), triple current (TM), and no (NM) management scenarios. Solid lines indicate statistical prediction using year as explanatory variable and dashed lines are $95 \%$ confidence bounds.

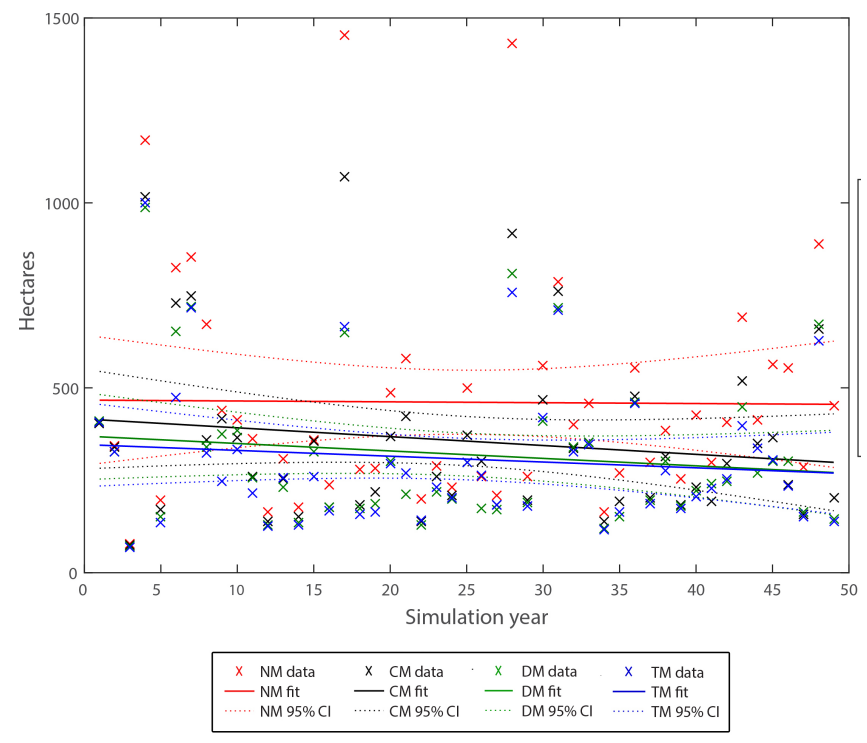

Table 2. Changes in overall burned area under current, double, and triple management scenarios compared with the no management scenario for different land designations. WUI = wildland urban interface.

\begin{tabular}{lccc}
\hline \hline Land designation & Current & Double & Triple \\
\hline Federal & $-25 \% *$ & $-36 \% *$ & $-40 \% *$ \\
Wilderness & $-4 \%$ & $-6 \%$ & $-7 \%$ \\
Old-growth & $-31 \% *$ & $-51 \% *$ & $-61 \% *$ \\
WUI & $-6 \%$ & $-9 \%$ & $-9 \%$ \\
\hline
\end{tabular}

$* \mathrm{p}<0.05$.

\section{Fire event analysis}

Under the no management scenario and across all simulation replicates, fires larger than 200 ha accounted for $92 \%$ of overall burned area. Very large fires (> 10,000 ha) accounted for $36 \%$ of overall burned area and occurred on 5 out of 1000 ignitions over a period of 50 years (Table 3 ). Compared to the no management scenario, all active management scenarios were effective in reducing the odds of a fire in all size classes (Fig. 4); however, the reduction was greatest for very large fires. The odds of a very large fire were approximately 0.60 to 1 ( $40 \%$ reduction) under current management and 0.30 to 1 ( $70 \%$ reduction) under the double and triple scenarios (Fig. 4D). Differences between double and triple scenarios were only marginally significant because of the overlapping confidence intervals. Over a period of 50 years our model estimated a decrease in the probability of a very large fire, from 5 in 1000, under no management, to 3 in 1000, under current management. Under the double and triple management scenarios the probability of a very large fire was 1.5 in 1000 and there was no statistical difference detected between the odds for these two scenarios.

Fig. 3. Cumulative area burned by stand replacing fire over time by management scenario: (A) federal lands, (B) Congressionally designated wilderness areas, $(\mathrm{C})$ designated old-growth reserves within the Deschutes National Forest, and (D) wildland urban interface as defined by SILVIS. Vertical bars indicate standard errors around the mean area burned over the 15 simulation replicates.
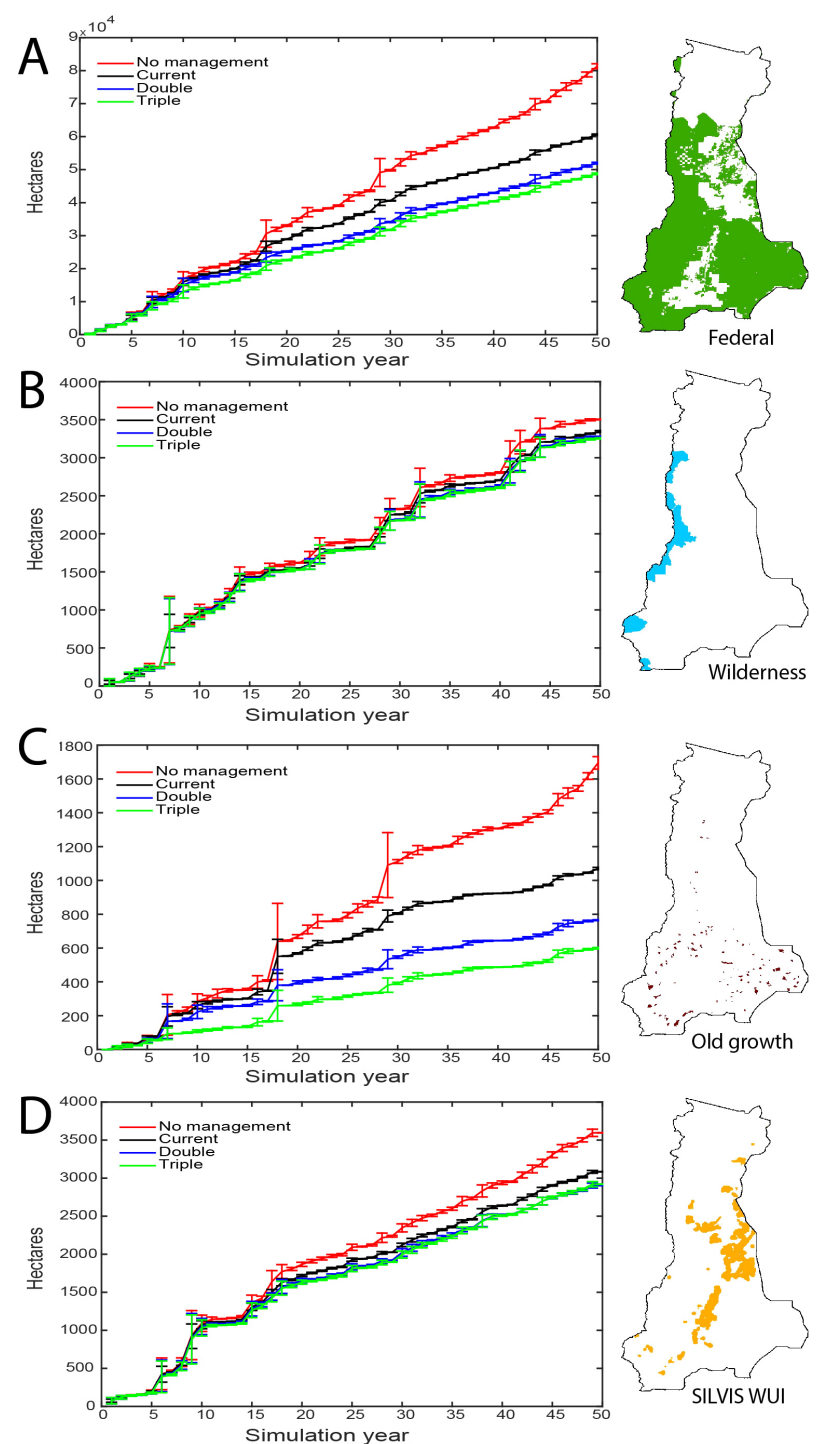
Table 3. Frequency of occurrence and share of total burned area of large fires under the no management scenario.

\begin{tabular}{lcccc}
\hline \hline & \multicolumn{4}{c}{ Fire size class (ha) } \\
\cline { 2 - 5 } & $>200$ & $>500$ & $>1000$ & $>10,000$ \\
\hline Size class frequency & $25 \%$ & $13 \%$ & $6.2 \%$ & $0.54 \%$ \\
$\%$ of total burned & $92 \%$ & $82 \%$ & $71 \%$ & $36 \%$ \\
area & & & & \\
\hline
\end{tabular}

\section{Treatment targets and availability}

Under current management, the annual treatment target for thinning was met $(>90 \%)$ for the entire simulation period (Fig. $5 \mathrm{~A})$. Under the double and triple management scenarios the annual target was fully met every year until year 20 and 15, respectively, after which the annual target was met at $40 \%$ and $20 \%$, respectively. Overall, total area treated with mechanical thinning during the 50 -year period is similar among scenarios: $2.1 \times 10^{5}$ ha under current management vs $2.4 \times 10^{5}$ ha under the double/triple current management scenarios. Treatment availability for mechanical thinning was slightly reduced under current management and furthermore reduced under the double/ triple scenarios after approximately $15 / 10$ years, i.e., at about the same time as a sharp decline was observed in the percentage of target met (Fig. 6A).

Fig. 4. Estimated odds (solid line) of an ignition becoming a fire larger than 200 ha (A), 500 ha (B), 1000ha (C), and 10,000 ha (D) and corresponding approximate pointwise $95 \%$ confidence intervals for the three simulated management scenarios $(\mathrm{CM}=$ current management; $\mathrm{DM}=$ double management; $\mathrm{TM}=$ triple management) relative to no management (NM, which is set to 1).
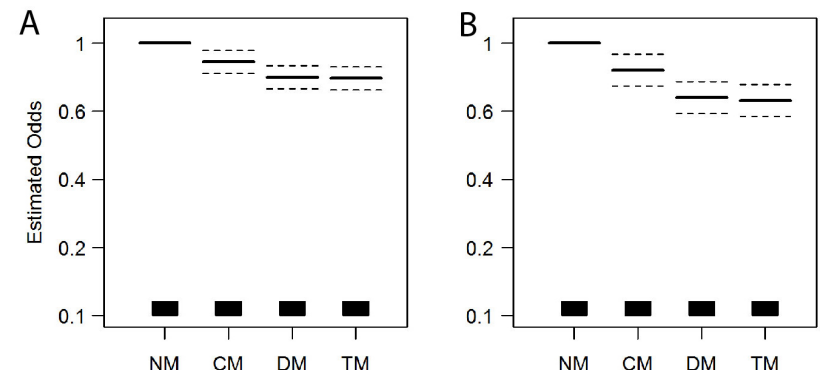

C
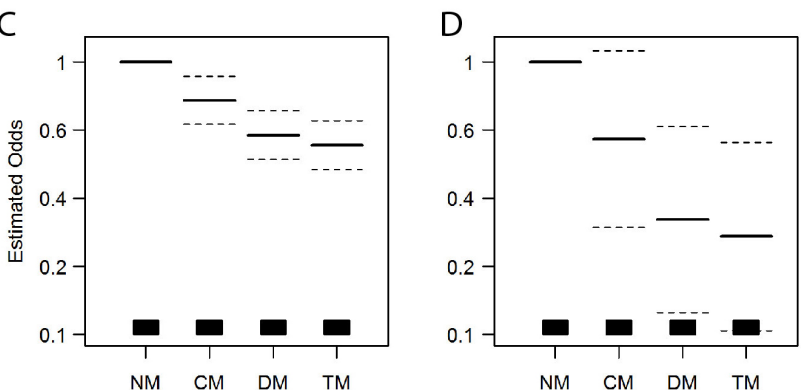

Fig. 5. Percentage of area target that was met on the landscape for each treatment/scenario: thinning (A), mastication (B), and prescribed fire (C). Values in each year correspond to average area treated in federal lands over the 15 simulation replicates and corresponding to one standard error bars (vertical bars).
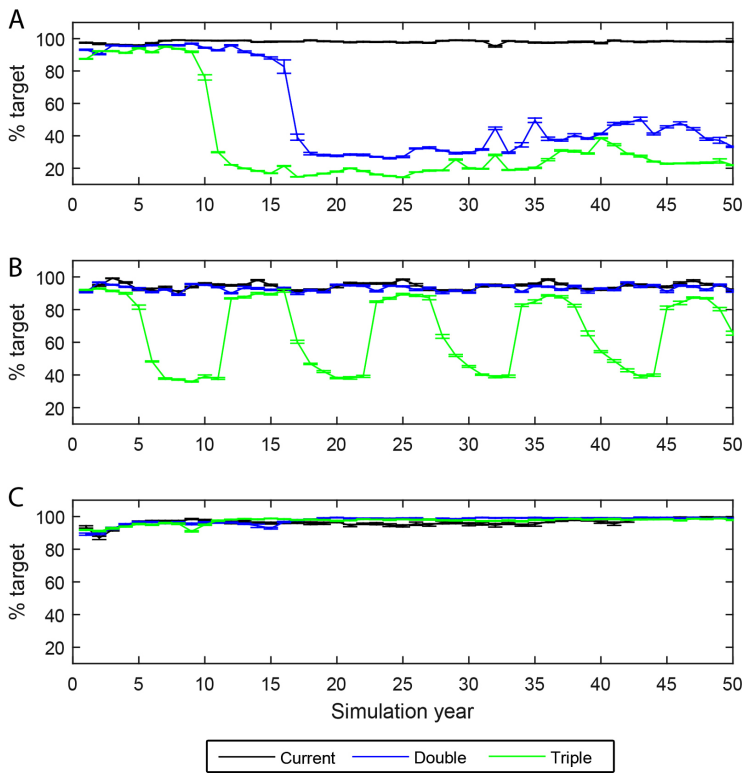

Fig. 6. Treatment availability on federal lands for each treatment/scenario: thinning (A), mastication (B), and prescribed fire (C). Values in each year correspond to average area available for treatment in federal lands over the 15 simulation replicates and corresponding one standard error bars (vertical bars).
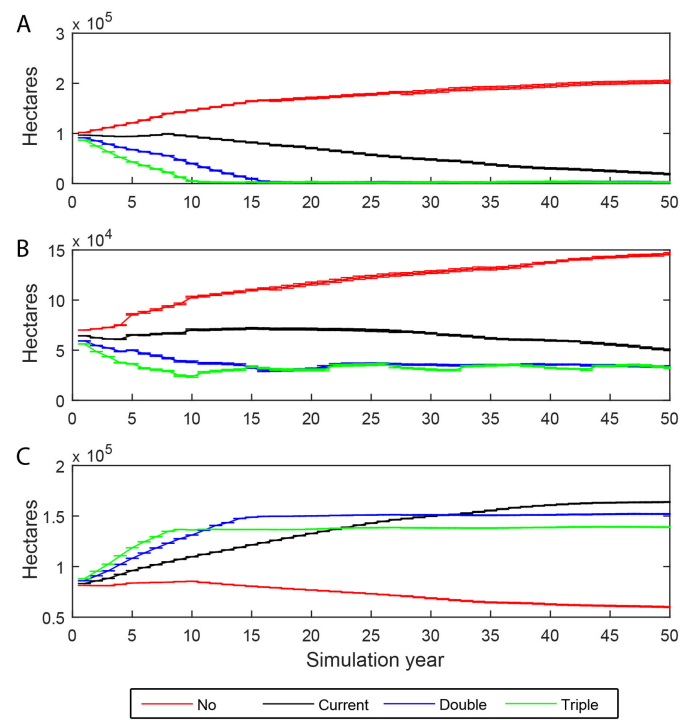
The annual target for mastication was met throughout the entire simulation period for both current and double current management scenarios. Under the triple current management scenario, the annual target fluctuated between $100 \%$ and $50 \%$ roughly every 5 years (Fig. 5B). Treatment availability for mastication was slightly reduced under all management scenarios (Fig. 6B). Not surprisingly, in the absence of management (red line in Figs. 6A and 6B), treatment availability increased over time for both mechanical treatments.

The annual area target for prescribed fire was largely met throughout the 50 years and for all management scenarios (Fig. 5C). However, contrary to what was observed for mechanical treatments, all active management scenarios led to higher landscape availability through time (Fig. 6C, black, green, and blue lines). Only under the no management scenario (Fig. 6C, red line) did we observe significant reductions in areas eligible for prescribed fire over a 50-year period.

\section{DISCUSSION}

The simulated wildfires under our no management scenario did not lead to increasing burned area over the 50-year period, therefore contradicting our original hypothesis. However, fuel was accumulating throughout the 50 years in forested stands available for thinning and mastication, i.e., excluding those in the wilderness. In fact, at the landscape scale, there was a $10 \%$ increase of heavy forest timber fuel models (and corresponding reduction in grass-shrub fuel models), with an associated increase in fuel load per unit area. The fact that we did not observe a concurrent increase in burned area suggests that the added fuel loads from vegetation succession did not translate into faster spread rates, but consisted instead of a conversion from relatively fast spreading grass-shrub models to heavy timber-litter models with moderate spread rate (e.g., low load compact conifer litter model; Scott and Burgan 2005). This conversion was accompanied by an increase in canopy cover, thus reducing wind speed and spread rate in the understory. The proportion of other fuel models remained the same over time, suggesting that the majority of the landscape is either in a stable successional state or changes in vegetation structure leading to transitions occur in time frames longer than 50 years.

In scenarios that simulated forest and fuel management, we hypothesized that accumulation of treated area would cause a downward trend in area burned. Overall, scenarios that included some level of management had less area burned. This is not surprising because treatments are capable of hindering subsequent fire spread as long as the ignition occurs in a treated area during the time the treatment remains effective, and under relatively favorable weather conditions (Strom and Fulé 2007). We observed a higher reduction in burned area in years with more (and larger) fires throughout the simulation period. This is in agreement with Syphard et al. (2011) and Loudermilk et al. (2014) who found that fuel treatments were more effective in reducing fire severity and sequestering forest carbon under severe fire weather because of an increased number of intersections between fires and treatments.

Management also reduced the likelihood of very large fires (> $10,000 \mathrm{ha}$ ) and that effect increased proportionately when area treated was doubled and tripled. Yet, under the double and triple management scenarios, annual rates of mechanical treatment were only met for the first two decades of simulation. Over the entire 50-year period the actual amount of forest thinned was, remarkably similar among scenarios, as treatment allocation was limited by the availability of suitable vegetation conditions. Current management can progressively but slowly address the backlog of the very specific structural conditions targeted by thinning: multistory, closed-canopy forest stands. However, areas suitable for thinning account for a small proportion (13\% at initial conditions) of the landscape, therefore the majority of the landscape remains untreated (Hampton et al. 2011, North et al. 2015). Allowing thinning in more open and/or smaller diameter stands would increase treatment availability to sustain higher targets for longer periods of time. The downside of expanding the structural restrictions on thinning is compromising the revenue that supports the cost of treatments if additional stands provide less volume per hectare treated.

Contrary to mechanical treatments, areas suitable for prescribed fire increased under all active management scenarios, and were only reduced under the no management scenario (red line, Fig. $6 \mathrm{C}$ ). We interpret this reduction as the result of the increased density of stands (from succession) that are not suitable for prescribed fire as the first action in a restoration sequence. The opposing trends in area suitable for treatment between these two types of management action are a likely consequence of the disproportionate treatment rates between thinning and prescribed fire, roughly 4400 ha vs 1300 ha treated per year (current management), respectively. Holding other factors constant, thinning increases the amount of single-story, open-canopy stands, thereby increasing the pool of area eligible for prescribed fire. These stands are in a condition to be safely burned in the years following thinning to reduce hazardous surface fuels and that was accounted for in our model (Collins et al. 2011). We suggest that at current rates (and with current spatial allocation rules), prescribed fire is not frequent enough to take advantage of the amount of thinning implemented on the landscape. This result highlights the need for an adequate balance of treatment targets, particularly for treatments that are coordinated, e.g., when mechanical thinning is supposed to be followed by prescribed fire.

The effect of management was particularly pronounced in designated old-growth areas that burned significantly less compared to the no management scenario. Old-growth forest reserves are distributed in small, dispersed land allocations, relatively distant from areas with frequent ignitions and imbedded within large areas of managed forest, thus benefiting from protection generated from treated areas. These "off-site" benefits of fuel management have been seen with both simulations (Ager et al. 2010, Stephens et al. 2014) and actual fires (Finney et al. 2005) and complement the treatment benefits made directly on site (Reinhardt et al. 2008).

In contrast to the old growth reserves, the amount of WUI burned was similar under all scenarios. WUI occupies large patches of land, mostly concentrated along frequent-ignition areas and is only partially within treatable areas thus it experiences higher wildfire exposure. These differences highlight how the efficacy of fuel management programs is affected by landscape context, priorities for protection, and how one measures the effectiveness of management actions (Ager et al. 2013). In this study, we assessed treatment effectiveness based on changes in burned area, 
but fuel and forest management programs may utilize other management objectives (and associated measures for success) such as forest restoration, biodiversity protection, or economic return. However, multiple objectives and priorities can lead to conflicting treatment allocations. For example, treating to reduce burned area/severity may imply treating locations that provide no economic return, while restricting treatments to areas where management pays for itself may have only a marginal effect on area burned/severity. Moreover, at landscape scale the outcome of fuel treatments is also determined by variables that are independent of treatment objectives such as proximity to ignition sources and to managed areas. This highlights the advantage of simulation methods capable of modeling how spatial allocation rules affect treatment efficacy through time (Ager et al. 2014a).

Despite the large fires seen in our simulations and witnessed in recent decades, there is a growing wildfire deficit in the western U.S.; biomass burning is low compared with historical fire activity and out of equilibrium with current climate (Marlon et al. 2012, Parks et al. 2015). Our fire model was calibrated with recent fire history data (1992 to 2009) and incorporated spatiotemporal patterns of ignition and fire size that are the direct result of the wildfire suppression policy in effect. Well-designed fuel management programs, combined with adequate suppression can protect communities from wildfire (Collins et al. 2010, North et al. 2012). However, relying on mechanical treatments alone to address the current wildfire deficit on landscapes with expanding WUI, increasing human ignitions and under a warming future, will create a challenging management situation. Allowing significantly more prescribed fire (and wildland fire management for resource benefit, which was not modeled in this study) would contribute toward a more resilient landscape. However, air quality regulations, as well as safety and liability concerns, combined with prohibitive fuel loads after a century of fire exclusion often limit efforts to increase the amount of fire (Miller 2002).

\section{Model limitations}

Envision links an STSM with wildfire and forest management submodels therefore, it inherits the limitations of these models. STSMs are representations of today's understanding of vegetation dynamics in a given ecological setting and thereby are dependent on available knowledge and data. This means that the only possible outcomes arising from an STSM are the outcomes defined by the states and transitions included in the model. To overcome such limitations users have modeled shorter temporal periods (Halofsky et al. 2014a) or relied on dynamic vegetation models to inform STSMs of likely future vegetation conditions (Kerns et al. 2011). The STSM in Envision includes dozens of vegetation states and several possible transitions between them with the total number of possible transitions in the thousands. This is a strong indication of the model's capacity to capture different behaviors that arise from interactions of fire, succession, and management. Moreover, Halofsky et al. (2014a) found that projected changes in area of forested potential vegetation types in central Oregon under climate change scenarios did not differ much from current conditions until at least 40-60 years from present. Given the 50-year period simulated in our study, and based on Halofsky et al. (2014a) we believe that the potential vegetation changes not available in the Envision STSM do not seriously limit our results.
The MTT algorithm used in the fire submodel has been widely tested and validated in both scientific and operational contexts. However, there are known limitations to this method given the assumption of constant fuel moisture, wind speed, and wind direction for a given ignition (Finney 2002). The fire ignition model was empirically based, therefore it reflects the interaction between suppression capability, climate, and fuel conditions of the past two decades. Simulating the contemporary fire regime into the future carries the implicit assumption that this interaction will remain constant. However, under a warmer future climate, suppression effectiveness may be reduced because of severe fire weather and longer fire seasons.

Our results overestimate the proportion of high-severity fire, and we believe this is a function of the flame length thresholds used in this analysis (see Spies et al. 2017). Further work will use MTBS fire severity data to calibrate flame length thresholds, so that modeled fire severity matches historical data.

\section{CONCLUSIONS}

Our modeling results indicate that over the course of 50 years and compared with no management, current forest management policy on federal lands would lead to reductions in burned area up to $25 \%$. Our results also suggest that constraints on the availability of suitable conditions limit treatment area in some federal landscapes. Doubling and tripling current levels could only be implemented for mechanical treatments over the first two decades of this simulation and led to a $40 \%$ reduction in burned area, while the likelihood of an ignition generating a fire $>10,000$ ha was reduced by threefold. However, although management reduced area burned, we did not observe a decreasing trend in burned area through time. This suggests that although forest and fuel management is a viable strategy to protect highly valued resources, it may not be capable of cumulatively altering the contemporary fire regime given current landscape conditions and management constraints.

At current rates, neither wildfire nor management were frequent enough to reduce fuel on a scale and extent that persists through time. It will require significant changes in the amount and/or distribution of management and wildfire in order to have an impact on landscape-level fuels, and consequently future wildfire. Our results show that increasing the amount of forest management is effective in the near future but limited by current management guidelines on treatment allocation. Further work is needed to evaluate at what levels fire and management interact to regulate fuel availability in the long-term. The failure to reduce burned area in the WUI reinforces the need to understand how spatial context, e.g., patch size, distance to ignition sources, and distance to managed lands, affects the ability of fuel management programs to reduce fire exposure to high valued-resources. Future work should also focus on analyzing the performance of forest and fuel management programs under prospective climate change futures and explore alternative sets of management policies, ranging from the current policy to increased rates of treatment and less restrictive allocation rules.

Responses to this article can be read online at: http://www.ecologyandsociety.org/issues/responses. php/8917 


\section{Acknowledgments:}

This research was funded by the National Science Foundation, Coupled Human and Natural Systems Program (NSF Grant CHH-1013296), the USDA Forest Service, PNW Research Station. We are thankful to Stuart Brittain, Alturas Solutions, for incorporating the FlamMap DLL into the wildfire submodel into the Envision system and James Sulzman for his programming work in the forest management and vegetation submodels.

\section{LITERATURE CITED}

Abatzoglou, J. T., and C. A. Kolden. 2013. Relationships between climate and macroscale area burned in the western United States. International Journal of Wildland Fire 22(7):1003-1020. http://dx. doi.org/10.1071/wf13019

Abatzoglou, J. T., D. E. Rupp, and P. W. Mote. 2014. Seasonal climate variability and change in the Pacific Northwest of the United States. Journal of Climate 27(5):2125-2142. http://dx.doi. org/10.1175/jcli-d-13-00218.1

Agee, J. K., and C. N. Skinner. 2005. Basic principles of forest fuel reduction treatments. Forest Ecology and Management 211:83-96. http://dx.doi.org/10.1016/j.foreco.2005.01.034

Ager, A. A., M. A. Day, C. W. McHugh, K. Short, J. GilbertsonDay, M. A. Finney, and D. E. Calkin. 2014a. Wildfire exposure and fuel management on western US national forests. Journal of Environmental Management 145:54-70. http://dx.doi.org/10.1016/ j.jenvman.2014.05.035

Ager, A. A., M. A. Finney, A. J. McMahan, and J. Cathcart. 2010. Measuring the effect of fuel treatments on forest carbon using landscape risk analysis. Natural Hazards and Earth System Sciences 10:2515-2526. http://dx.doi.org/10.5194/nhess-10-2515-2010

Ager, A. A., H. K. Preisler, B. Arca, D. Spano, and M. Salis. $2014 b$. Wildfire risk estimation in the Mediterranean area. Environmetrics 25(6):384-396. http://dx.doi.org/10.1002/env.2269

Ager, A. A., N. M. Vaillant, and A. McMahan. 2013. Restoration of fire in managed forests: a model to prioritize landscapes and analyze tradeoffs. Ecosphere 4(2):1-19. http://dx.doi.org/10.1890/ ES13-00007.1

Baker, W. L. 2015. Are high-severity fires burning at much higher rates recently than historically in dry-forest landscapes of the Western USA? PLoS ONE 10(9):e0136147. http://dx.doi. org/10.1371/journal.pone.0136147

Bolte, J. P., D. W. Hulse, S. V. Gregory, and C. Smith. 2007. Modeling biocomplexity - actors, landscapes and alternative futures. Environmental Modelling \& Software 22(5):570-579. http://dx.doi.org/10.1016/j.envsoft.2005.12.033

Brown, T. J., B. L. Hall, and A. L. Westerling. 2004. The impact of twenty-first century climate change on wildland fire danger in the Western United States: an application perspective. Climate Change 62:365-388. http://dx.doi.org/10.1023/B:CLIM.0000013680.07783. $\underline{\text { de }}$

Collins, B. L., S. L. Stephens, G. Roller, and J. J. Battles. 2011. Simulating fire and forest dynamics for a landscape fuel treatment project in the Sierra Nevada. Forest Science 57(2):77-88.
Collins, B. M., S. L. Stephens, J. J. Moghaddas, and J. Battles. 2010. Challenges and approaches in planning fuel treatments across fire-excluded forested landscapes. Journal of Forestry 108:24-31.

Dixon, G. E. 2002. Essential FVS: a user's guide to the Forest Vegetation Simulator. Internal Report, U.S. Forest Service, Forest Management Service Center, Fort Collins, Colorado, USA. [online] URL: http://www.fs.fed.us/fmsc/ftp/fvs/docs/gtr/EssentialFVS. pdf

Finney, M. A. 2001. Design of regular landscape fuel treatment patterns for modifying fire growth and behavior. Forest Science 47:219-228.

Finney, M. A. 2002. Fire growth using minimum travel time methods. Canadian Journal of Forest Research 32:1420-1424. http://dx.doi.org/10.1139/x02-068

Finney, M. A. 2007. A computational method for optimizing fuel treatment location. International Journal of Wildland Fire 16:702-711. http://dx.doi.org/10.1071/WF06063

Finney, M. A., C. W. McHugh, and I. C. Grenfell. 2005. Standand landscape-level effects of prescribed burning on two Arizona wildfires. Canadian Journal of Forest Research 35:1714-1722. http://dx.doi.org/10.1139/x05-090

Gustafson, E. J., A. Z. Shividenko, B. R. Sturtevant, and R. M. Scheller. 2010. Predicting global change effects on forest biomass and composition in south-central Siberia. Ecological Applications 20(3):700-715. http://dx.doi.org/10.1890/08-1693.1

Halofsky, J. E., M. K. Creutzburg, and M. A. Hemstrom. $2014 b$. Integrating social, economic, and ecological values across large landscapes. General Technical Report. PNW-GTR-896, U.S. Forest Service, Pacific Northwest Research Station, Portland, Oregon, USA.

Halofsky, J. S., J. E. Halofsky, T. Burcsu, and M. A. Hemstrom. 2014a. Dry forest resilience varies under simulated climatemanagement scenarios in a central Oregon, USA landscape. Ecological Applications 24(8):1908-1925. http://dx.doi. org/10.1890/13-1653.1

Hampton, H. M., S. E. Sesnie, J. D. Bailey, and G. B. Snider. 2011. Estimating regional wood supply based on stakeholder consensus for forest restoration in northern Arizona. Journal of Forestry 109:16-26.

Hemstrom, M., A. A. Ager, M. Vavra, B. C. Wales, and M. J. Wisdom. 2004. A state and transition approach for integrated landscape models. Pages 17-32 in J. L. Hayes, A. A. Ager, and R. J. Barbour, editors. Methods for integrating modeling of landscape change: Interior Northwest Landscape Analysis System. General Technical Report PNW-GTR-610. U.S. Forest Service, Pacific Northwest Research Station, Portland, Oregon, USA.

Hemstrom, M. A., J. Merzenich, A. Reger, and B. Wales. 2007. Integrated analysis of landscape management scenarios using state and transition models in the upper Grande Ronde River Subbasin, Oregon, USA. Landscape and Urban Planning 80 (3):198-211. http://dx.doi.org/10.1016/j.landurbplan.2006.10.004

Hessburg, P. F., J. K. Agee, and J. F. Franklin. 2005. Dry forests and wildland fires of the inland Northwest USA: contrasting the 
landscape ecology of the pre-settlement and modern eras. Forest Ecology and Management 211(1-2):117-139. http://dx.doi. org/10.1016/i.foreco.2005.02.016

Hessburg, P. F., R. B. Salter, and K. M. James. 2007. Re-examining fire severity relations in pre-management era mixed conifer forests: inferences from landscape patterns of forest structure. Landscape Ecology 22:5-24. http://dx.doi.org/10.1007/s10980-007-9098-2

Hessburg, P. F., T. A. Spies, D. A. Perry, C. N. Skinner, A. H. Taylor, P. M. Brown, S. L. Stephens, A. J. Larson, D. J. Churchill, N. A. Povak, P. H. Singleton, B. McComb, W. J. Zielinski, B. M. Collins, R. B. Salter, J. J. Keane, J. F. Franklin, and G. Riegel. 2016. Tamm Review: management of mixed-severity fire regime forests in Oregon, Washington, and Northern California. Forest Ecology and Management 366:221-250. http://dx.doi.org/10.1016/ j.foreco.2016.01.034

Hessl, A. E., D. McKenzie, and R. Schellhaas. 2004. Drought and Pacific Decadal Oscillation linked to fire occurrence in the inland Pacific Northwest. Ecological Applications 14(2):425-442. http:// dx.doi.org/10.1890/03-5019

Heyerdahl, E. K., L. B. Brubaker, and J. K. Agee. 2002. Annual and decadal climate forcing of historical fire regimes in the interior Pacific Northwest, USA. Holocene 12(5):597-604. http:// dx.doi.org/10.1191/0959683602h1570rp

Jolly, W. M., M. A. Cochrane, P. H. Freeborn, Z. A. Holden, T. J. Brown, G. J. Williamson, and D. M. J. S. Bowman. 2015. Climate-induced variations in global wildfire danger from 1979 to 2013. Nature Communications 6:7537. http://dx.doi. org/10.1038/ncomms 8537

Kerns, B. K., M. A. Hemstrom, D. Conklin, G. I. Yospin, B. Johnson, D. Bachelet, and S. Bridgham. 2011. Approaches to incorporating climate change effects in state and transition simulation models of vegetation. Pages 161-171 in B. K. Kerns, A. J. Shlisky, and J. Colin, editors. Proceedings of the First Landscape State-and-Transition Simulation Modeling Conference. General Technical Report PNW-GTR-869. U.S. Forest Service, Pacific Northwest Research Station, Portland, Oregon, USA.

Littell, J. S., D. McKenzie, D. L. Peterson, and A. L. Westerling. 2009. Climate and wildfire area burned in western U.S. ecoprovinces, 1916-2003. Ecological Applications 19(4):1003-1021. http://dx.doi.org/10.1890/07-1183.1

Loudermilk, E. L., A. Stanton, R. M. Scheller, T. E. Dilts, P. J. Weisberg, C. Skinner, and J. Yang. 2014. Effectiveness of fuel treatments for mitigating wildfire risk and sequestering forest carbon: a case study in the Lake Tahoe Basin. Forest Ecology and Management 323:114-125. http://dx.doi.org/10.1016/j.foreco.2014.03.011

Marlon, J. R., P. J. Bartlein, D. G. Gavin, C. J. Long, R. S. Anderson, C. E. Briles, K. J. Brown, D. Colombaroli, D. J. Hallett, M. J. Power, E. A. Scharf, and M. K. Walsh. 2012. Long-term perspective on wildfires in the western USA. Proceedings of the National Academy of Sciences of the United States of America 109(9):E535-E543. http://dx.doi.org/10.1073/pnas.1112839109

Merschel, A. G., T. A. Spies, and E. K. Heyerdahl. 2014. Mixedconifer forests of central Oregon: effects of logging and fire exclusion vary with environment. Ecological Applications 24 (7):1670-1688. http://dx.doi.org/10.1890/13-1585.1
Miller, C. 2002. Wildland fire use: a wilderness perspective on fuel management. Pages 379-385 in P. N. Omni and L. Joyce, editors. Fire, fuel treatments, and ecological restoration: conference proceedings. Proceedings RMRS-P-29. U.S. Forest Service, Rocky Mountain Research Station, Fort Collins, Colorado, USA.

Miller, J. D., H. D. Safford, M. Crimmins, and A. E. Thode. 2009. Quantitative evidence for increasing forest fire severity in the Sierra Nevada and southern Cascade Mountains, California and Nevada, USA. Ecosystems 12(1):16-32. http://dx.doi.org/10.1007/ $\underline{\text { 10021-008-9201-9 }}$

Mote, P. W. 2003. Trends in temperature and precipitation in the Pacific Northwest during the twentieth century. Northwest Science 77(4):271-282.

North, M., A. Brough, J. Long, B. Collins, P. Bowden, D. Yasuda, J. Miller, and N. Sugihara. 2015. Constraints on mechanized treatment significantly limit mechanical fuels reduction extent in the Sierra Nevada. Journal of Forestry 113(1):40-48. http://dx.doi. org/10.5849/jof.14-058

North, M., B. M. Collins, and S. Stephens. 2012. Using fire to increase the scale, benefits, and future maintenance of fuels treatments. Journal of Forestry 110(7):392-401. http://dx.doi. org/10.5849/jof.12-021

Noss, R. F., J. F. Franklin, W. L. Baker, T. Schoennagel, and P. B. Moyle. 2006. Managing fire-prone forests in the western United States. Frontiers in Ecology and the Environment 4:481-487. http:// dx.doi.org/10.1890/1540-9295(2006)4[481:MFFITW]2.0.CO;2

Odion, D. C., C. T. Hanson, A. Arsenault, W. L. Baker, D. A. DellaSala, R. L. Hutto, W. Klenner, M. A. Moritz, R. L. Sherriff, T. T. Veblen, and M. A. Williams. 2014. Examining historical and current mixed-severity fire regimes in ponderosa pine and mixedconifer forests of western North America. PLOS ONE 9(2): e87852. http://dx.doi.org/10.1371/journal.pone.0087852

Odion, D. C., C. T. Hanson, W. L. Baker, D. A. DellaSala, and M. A. Williams. 2016. Areas of agreement and disagreement regarding ponderosa pine and mixed conifer forest fire regimes: a dialogue with Stevens et al. PLOS ONE 11(5):e0154579. http:// dx.doi.org/10.1371/journal.pone.0154579

Ohmann, J. L., M. J. Gregory, E. B. Henderson, and H. M. Roberts. 2011. Mapping gradients of community composition with nearest-neighbour imputation: extending plot data for landscape analysis. Journal of Vegetation Science 22(4):660-676. http://dx.doi.org/10.1111/j.1654-1103.2010.01244.x

Parisien, M.-A., D. R. Junor, and V. G. Kafka. 2007. Comparing landscape-based decision rules for placement of fuel treatments in the boreal mixedwood of western Canada. International Journal of Wildland Fire 16:664-672. http://dx.doi.org/10.1071/ $\underline{\mathrm{WF} 06060}$

Parks, S. A., C. Miller, M.-A. Parisien, L. M. Holsinger, S. Z. Dobrowski, and J. Abatzoglou. 2015. Wildland fire deficit and surplus in the western United States, 1984-2012. Ecosphere 6 (12):1-13. http://dx.doi.org/10.1890/ES15-00294.1

Perry, D. A., P. F. Hessburg, C. N. Skinner, T. A. Spies, S. L. Stephen, A. H. Taylor, J. F. Franklin, B. McComb, and G. Riegel. 2011. The ecology of mixed severity fire regimes in Washington, 
Oregon, and northern California. Forest Ecology and Management 262:703-717. http://dx.doi.org/10.1016/j.foreco.2011.05.004

Peters, D. P. C., R. A. Pielke Sr, B. T. Bestelmeyer, C. D. Allen, S. Munson-McGee, and K. M. Havstad. 2004. Cross-scale interactions, nonlinearities, and forecasting catastrophic events. Proceeding of the National Academy of Science USA 101 (42):15130-15135. http://dx.doi.org/10.1073/pnas.0403822101

Preisler, H. K. and A. A. Ager. 2013. Forest-fire models. Pages 1081-1088 in A. H. El-Shaarawi and W. Piegorsch, editors. Encyclopedia of environmetrics. John Wiley \& Sons, Chichester, UK. http://dx.doi.org/10.1002/9780470057339.vaf010.pub2

Preisler, H. K., D. R. Brillinger, R. E. Burgan, and J. W. Benoit. 2004. Probability based models for estimating wildfire risk. International Journal of Wildland Fire 13:133-142. http://dx.doi. org/10.1071/WF02061

R Core Team. 2014. R: A language and environment for statistical computing. Version 3.1.1. The R Project for Statistical Computing, Vienna, Austria. [online] URL: http://www.R-project.org/

Radeloff, V. C., R. B. Hammer, S. I. Stewart, J. S. Fried, S. S. Holcomb, and J. F. McKeefry. 2005. The wildland-urban interface in the United States. Ecological Applications 15:799-805. http:// dx.doi.org/10.1890/04-1413

Reinhardt, E. D., R. E. Keane, D. E. Calkin, and J. D. Cohen. 2008. Objectives and considerations for wildland fuel treatment in forested ecosystems of the interior western United States. Forest Ecology and Management 256:1997-2006. http://dx.doi. org/10.1016/j.foreco.2008.09.016

Rollins, M. G. 2009. LANDFIRE: a nationally consistent vegetation, wildland fire, and fuel assessment. International Journal of Wildland Fire 18:235-249. http://dx.doi.org/10.1071/ $\underline{\mathrm{WF} 08088}$

Scheller, R. M., and D. J. Mladenoff. 2005. A spatially interactive simulation of climate change, harvesting, wind, and tree species migration and projected changes to forest composition and biomass in northern Wisconsin, USA. Global Change Biology 11:307-321. http://dx.doi.org/10.1111/j.1365-2486.2005.00906.x

Schmidt, D. A., A. H. Taylor, and C. N. Skinner. 2008. The influence of fuels treatment and landscape arrangement on simulated fire behavior, southern Cascade Range, California. Forest Ecology and Management 255:3170-3184. http://dx.doi. org/10.1016/j.foreco.2008.01.023

Scott, J. H. and R. E. Burgan. 2005. Standard fire behavior fuel models: a comprehensive set for use with Rothermel's surface fire spread model. General Technical Report RMRS-GTR-153, U.S. Forest Service, Rocky Mountain Research Station, Fort Collins, Colorado, USA.

Sherriff, R. L., R. V. Platt, T. T. Veblen, T. L. Schoennagel, and M. H. Gartner. 2014. Historical, observed, and modeled wildfire severity in montane forests of the Colorado Front Range. PLoS ONE 9(9):e106971. http://dx.doi.org/10.1371/journal.pone.0106971

Short, K. C. 2015. Spatial wildfire occurrence data for the United States, 1992-2013 [FPA_FOD_20150323]. Third edition. U.S. Forest Service, Rocky Mountain Research Station, Fort Collins, Colorado, USA. http://dx.doi.org/10.2737/RDS-2013-0009.3
Slocum, M. G., B. Beckage, W. J. Platt, S. L. Orzell, and W. Taylor. 2010. Effect of climate on wildfire size: a cross-scale analysis. Ecosystems 13:828-840. http://dx.doi.org/10.1007/s10021-010-9357y

Spies, T. A., E. White, A. Ager, J. D. Kline, J. P. Bolte, E. K. Platt, K. A. Olsen, R. J. Pabst, A. M.G. Barros, J. D. Bailey, S. Charnley, J. Koch, M. M. Steen-Adams, P. H. Singleton, J. Sulzman, C. Schwartz, and B. Csuti. 2017. Using an agent-based model to examine forest management outcomes in a fire-prone landscape in Oregon, USA. Ecology and Society 22(1):25. https://doi. org/10.5751/ES-08841-220125

Spies, T. A., E. M. White, J. D. Kline, A. P. Fischer, A. Ager, J. Bailey, J. Bolte, J. Koch, E. Platt, C. S. Olsen, D. Jacobs, B. Shindler, M. M. Steen-Adams, and R. Hammer. 2014. Examining fire-prone forest landscapes as coupled human and natural systems. Ecology and Society 19(3):9. http://dx.doi.org/10.5751/ ES-06584-190309

Spracklen, D. V., L. J. Mickley, J. A. Logan, R. C. Hudman, R. Yevich, M. D. Flannigan, and A. L. Westerling. 2009. Impacts of climate change from 2000 to 2050 on wildfire activity and carbonaceous aerosol concentrations in the western United States. Journal of Geophysical Research 114:1-17. http://dx.doi. org/10.1029/2008JD010966

Stavros, E. N., J. T. Abatzoglou, D. McKenzie, and N. K. Larkin. 2014. Regional projections of the likelihood of very large wildland fires under a changing climate in the contiguous Western United States. Climatic Change 126(3-4):455-468. http://dx.doi. org/10.1007/s10584-014-1229-6

Stephens, S. L., S. W. Bigelow, R. D. Burnett, B. M. Collins, C. V. Gallagher, J. Keane, D. A. Kelt, M. P. North, L. J. Roberts, P. A. Stine, and D. H. Van Vuren. 2014. California spotted owl, songbird, and small mammal responses to landscape fuel treatments. BioScience 64(10):893-906. http://dx.doi.org/10.1093/ biosci/biu137

Stevens, J. T., H. D. Safford, M. P. North, J. S. Fried, A. N. Gray, P. M. Brown, C. R. Dolanc, S. Z. Dobrowski, D. A. Falk, C. A. Farris, J. F. Franklin, P. Z. Fulé, R. K. Hagmann, E. E. Knapp, J. D. Miller, D. F. Smith, T. W. Swetnam, and A. H. Taylor. 2016. Average stand age from forest inventory plots does not describe historical fire regimes in ponderosa pine and mixed-conifer forests of western North America. PLoS ONE 11(5):e0147688. 10.1371/ journal.pone.0147688 http://dx.doi.org/10.1371/journal.pone.0147688

Strom, B. A. and P. Z. Fulé. 2007. Pre-wildfire fuel treatments affect long-term ponderosa pine forest dynamics. International Journal of Wildland Fire 16(1):128-138. http://dx.doi.org/10.1071/ wf06051

Syphard, A. D., R. M. Scheller, B. C. Ward, W. D. Spencer, and J. R. Strittholt. 2011. Simulating landscape-scale effects of fuels treatments in the Sierra Nevada, California, USA. International Journal of Wildland Fire 20(3):364-383. http://dx.doi.org/10.1071/ $\underline{\text { wf09125 }}$

Taylor, M. H., K. Rollins, M. Kobayahsi, and R. J. Tausch. 2013. The economics of fuel management: wildfire, invasive plants, and the dynamics of sagebrush rangelands in the western United States. Journal of Environmental Management 126:157-173. http:// dx.doi.org/10.1016/j.jenvman.2013.03.044 
Thompson, J. R., and T. A. Spies. 2009. Vegetation and weather explain variation in crown damage within a large mixed severity wildfire. Forest Ecology and Management 258:1684-1694. http:// dx.doi.org/10.1016/j.foreco.2009.07.031

U.S. Congress. 2003. Healthy Forest Restoration Act of 2003. U. S. Congress, Washington, D.C., USA.

U.S. Forest Service(USFS). 1990. Deschutes National Forest: land and resource management plan. U.S. Forest Service, Pacific Northwest Region, Portland, Oregon, USA.

U.S. Forest Service and U.S. Geological Survey (USFS and USGS). 2009. Monitoring trends in burn severity (MTBS). National Geospatial Data. U.S. Forest Service, Washington, D.C., USA and U.S. Geological Survey, Reston, Virginia, USA. [online] URL: http://mtbs.gov/nationalregional/intro.html

Vogler, K. C., A. A. Ager, M. A. Day, M. Jennings, and J. D. Bailey. 2015. Prioritization of forest restoration projects: tradeoffs between wildfire protection, ecological restoration and economic objectives. Forests 6:4403-4420. http://dx.doi.org/10.3390/ $\underline{\mathrm{f} 6124375}$

Weatherspoon, C. P., S. J. Husari, and J. W. Van Wagtendonk. 1992. Fire and fuels management in relation to owl habitat in forests of the Sierra Nevada and southern California. Pages 247-260 in J. Verner, K. S. McKelvey, B. R. Noon, R. J. Gutierrez, G. I. Gould Jr., and T. W. Beck, editors. The California spotted owl: a technical assessment of its current status. General Technical. Report PSW-GTR-133. U.S. Forest Service, Pacific Southwest Research Station, Albany, California, USA.

Westerling, A. L. 2016. Increasing western US forest wildfire activity: sensitivity to changes in the timing of spring. Philosophical Transactions of the Royal Society B-Biological Sciences 371:20150178. http://dx.doi.org/10.1098/rstb.2015.0178

Westerling, A. L., H. G. Hidalgo, D. R. Cayan, and T. W. Swetnam. 2006. Warming and earlier spring increase western U. S. forest wildfire activity. Science 313:940-943. http://dx.doi. org/10.1126/science. 1128834

Williams, J. 2013. Exploring the onset of high-impact mega-fires through a forest land management prism. Forest Ecology and Management 294:4-10. http://dx.doi.org/10.1016/j.foreco.2012.06.030

Yospin, G. I., S. D. Bridgham, R. P. Neilson, J. P. Bolte, D. M. Bachelet, P. J. Gould, C. A. Harrington, J. A. Kertis, C. Evers, and B. R. Johnson. 2015. A new model to simulate climate change impacts on forest succession for local land management. Ecological Applications 25(1):226-242. http://dx.doi.org/10.1890/13-0906.1 
Appendix 1. Conceptual model of Envision's components.

Fig. A1.1. Overview of Envisions components, from Spies et al. (2017). Agents on the landscape have goals based on forest policies, markets and personal objectives for the land they manage. To achieve their goals, agents act on the landscape - e.g. cut trees, manage fuels, firewise their homes - and those actions are modeled the forest management allocator submodel. Simultaneously, the landscape is affected by wildfire, vegetation succession and housing expansion, autonomous change processes that are independent of actor behavior, alter landscape conditions and affect where and how agent's goals are achieved. At the end of each time step landscape evaluators quantify the production of different landscape services (e.g., wood production, biodiversity, carbon) and the combined effect of all processes - agent dependent and autonomous - will determine landscape condition which feedbacks into the simulation for the following time step.

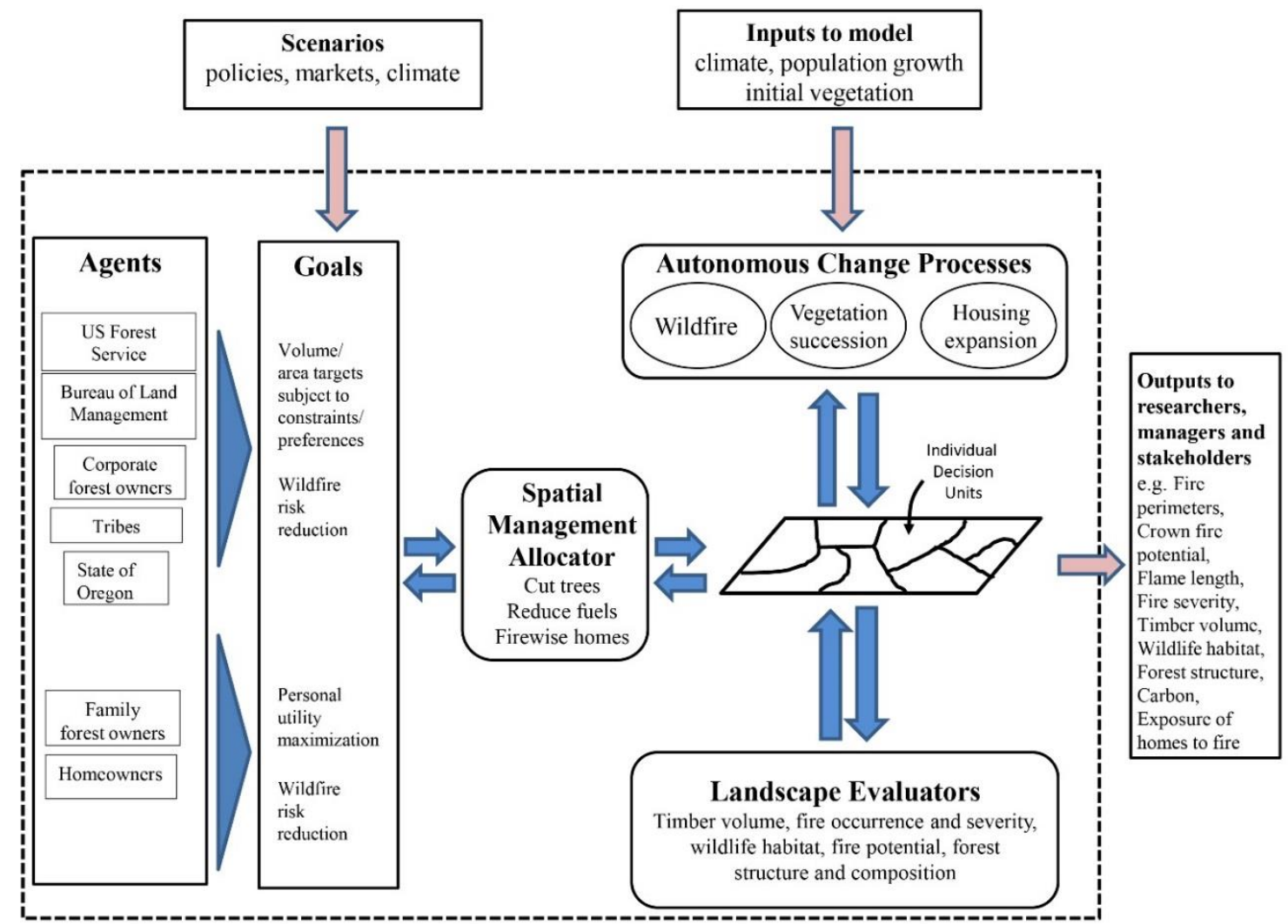

\section{LITERATURE CITED}

Spies, T. A., E. White, A. Ager, J. D. Kline, J. P. Bolte, E. K. Platt, K. A. Olsen, R. J. Pabst, A. M.G. Barros, J. D. Bailey, S. Charnley, J. Koch, M. M. Steen-Adams, P. H. Singleton, J. Sulzman, C. Schwartz, and B. Csuti. 2017. Using an agent-based model to examine forest management outcomes in a fire-prone landscape in Oregon, USA. Ecology and Society 22(1):25. http://dx.doi.org/10.5751/ES-08841-210125 
Appendix 2. Effects of wildfire and forest management in vegetation descriptors.

Table A2.1. Changes in canopy cover and surface fuels as a function of wildfire severity and treatment action.

\begin{tabular}{|c|c|c|}
\hline Disturbance & Effect on canopy cover & Effect on surface fuels \\
\hline Surface fire or prescribed fire & No change & Reduces surface fuels \\
\hline Mixed severity fire & $\begin{array}{l}\text { Decreases canopy cover by one or } \\
\text { two classes }\end{array}$ & Reduces surface fuels \\
\hline Stand-replacing fire & $\begin{array}{l}\text { Decreases canopy cover to low } \\
(20 \%) \text { or none }\end{array}$ & Reduces surface fuels \\
\hline Surface treatments & No change & Increases surface fuels \\
\hline Thinning & $\begin{array}{l}\text { Decreases canopy cover from high } \\
(>60 \%) \text { to moderate }(60-40 \%)\end{array}$ & Increases surface fuels \\
\hline Clear cut & $\begin{array}{l}\text { Decreases canopy cover to low } \\
(20 \%) \text { or none }\end{array}$ & Increases surface fuels \\
\hline Partial harvest (heavy) & $\begin{array}{l}\text { Decreases canopy cover by one or } \\
\text { two classes }\end{array}$ & Increases surface fuels \\
\hline
\end{tabular}

Table A2.2. Fuel model codes asssigned to post-disturbance conditions. All models are described in Scott and Burgan (2005) with exception of MAST, a custom fuel model for masticated fuel beds.

\begin{tabular}{cccccc}
\hline \hline Baseline & $\begin{array}{c}\text { Surface fire } \\
\text { or prescribed } \\
\text { fire }\end{array}$ & $\begin{array}{c}\text { Mixed } \\
\text { severity fire }\end{array}$ & $\begin{array}{c}\text { Stand- } \\
\text { replacing fire }\end{array}$ & Mastication & Thinning \\
\hline $\begin{array}{c}\text { Until } \\
\text { transition/ }\end{array}$ & 10 years & 10 years & 10 years & 5 years & 5 years \\
disturbance & & & & & \\
NB3 & NB3 & NB3 & NB3 & NB3 & NB3 \\
NB8 & NB8 & NB8 & NB8 & NB8 & NB8 \\
GR1 & TL1 & GR1 & TL1 & GR1 & GR1 \\
GR2 & TL2 & GR2 & TL1 & GR2 & GR2 \\
GR3 & TL2 & GR2 & TL1 & GR2 & GR3 \\
GS1 & TL2 & GS1 & TL1 & MAST & TL5 \\
GS2 & TL2 & GR2 & TL1 & MAST & TL5 \\
SH1 & TL2 & GS1 & TL1 & MAST & TL5 \\
SH2 & TL2 & GS2 & TL1 & MAST & TL5 \\
TU1 & TL2 & GR2 & TL1 & MAST & TL5 \\
TU4 & TL1 & TL1 & TL1 & MAST & TL5 \\
TU5 & TL1 & TL1 & TL1 & MAST & TL5 \\
TL1 & TL1 & TL1 & TL1 & MAST & TL5 \\
TL2 & TL1 & TL1 & TL1 & MAST & TL5 \\
TL3 & TL1 & TL1 & TL1 & MAST & TL5
\end{tabular}




\begin{tabular}{llllll} 
TL4 & TL1 & TL1 & TL1 & MAST & TL5 \\
TL5 & TL1 & TL1 & TL1 & MAST & TL5 \\
TL6 & TL1 & TL1 & TL1 & MAST & TL5 \\
TL7 & TL1 & TL1 & TL1 & MAST & TL5 \\
TL8 & TL1 & TL1 & TL1 & MAST & TL5 \\
TL9 & TL1 & TL1 & TL1 & MAST & TL5 \\
\hline
\end{tabular}

\section{LITERATURE CITED}

Scott, J. H. and R. E. Burgan. 2005. Standard fire behavior fuel models: a comprehensive set for use with Rothermel's surface fire spread model. Gen. Tech. Rep. RMRS-GTR-153, USDA Forest Service, Rocky Mountain Research Station. 
Appendix 3. Constraints and preference weights used in treatment allocations.

Table A3.1. Sets of constraints defining where treatments can occur for different treatment actions and landowners.

\begin{tabular}{|c|c|c|c|}
\hline Landowner & Action & Patch size & Where \\
\hline \multirow{12}{*}{ FEDERAL } & \multirow{6}{*}{ Thinning } & \multirow{6}{*}{$\begin{array}{c}\text { Normal } \\
\text { distribution } \\
\mathrm{N}(50,10)\end{array}$} & Ponderosa pine with $\mathrm{dbh}>25 \mathrm{~cm}$ \\
\hline & & & Lodgpeole pine with $\mathrm{dbh}>25 \mathrm{~cm}$ \\
\hline & & & Dry mixed conifer with $>25 \mathrm{~cm}$ \\
\hline & & & Multistory canopies \\
\hline & & & Closed canopies ( $>60 \%$ cover $)$ \\
\hline & & & Time since last thinning action $>14$ years \\
\hline & Mastication & 40 ha & $\begin{array}{l}\text { Forested areas with fuel models SH5, SH7 or TU5 } \\
\text { Time since last mastication }>9 \text { years }\end{array}$ \\
\hline & \multirow{5}{*}{ Prescribed fire } & \multirow{5}{*}{40 ha } & Dry mixed conifer with $\mathrm{dbh}>25 \mathrm{~cm}$ \\
\hline & & & Ponderosa pine with $\mathrm{dbh}>25 \mathrm{~cm}$ \\
\hline & & & Single story \\
\hline & & & Open canopies \\
\hline & & & Time since last prescribed fire $>9$ years \\
\hline \multirow{21}{*}{ TRIBAL } & \multirow{9}{*}{ Thinning } & \multirow{9}{*}{30 ha } & Lodgepole pine with age $>70$ years \\
\hline & & & Mountain hemlock with age $>70$ years \\
\hline & & & Moist mixed conifer with age $>40$ years \\
\hline & & & Dry mixed conifer with age $>40$ years \\
\hline & & & Western hemlock with age $>60$ years \\
\hline & & & Western white pine with age $>60$ years \\
\hline & & & Pacific silver fir/Douglas fir with age $>60$ years \\
\hline & & & Western larch/lodgepole pine with age $>60$ years \\
\hline & & & Alpine/high elevation with age $>70$ years \\
\hline & \multirow{9}{*}{ Clearcutting } & \multirow{9}{*}{20 ha } & Lodgepole pine with age $>130$ years \\
\hline & & & Mountain hemlock with age $>130$ years \\
\hline & & & Moist mixed conifer with age $>70$ years \\
\hline & & & Dry mixed conifer with age $>70$ years \\
\hline & & & Western hemlock with age $>120$ years \\
\hline & & & Pacific silver fir/Douglas fir with age $>120$ years \\
\hline & & & Western white pine with age $>90$ years \\
\hline & & & Western larch/lodgepole pine with age $>90$ years \\
\hline & & & Other alpine forest types with age $>130$ years \\
\hline & \multirow{3}{*}{ Prescribed fire } & \multirow{3}{*}{81 ha } & Ponderosa pine \\
\hline & & & Douglas fir \\
\hline & & & Dry mixed conifers \\
\hline
\end{tabular}

Weibull

INDUSTRIAL Partial harvest Distribution Any forest type with dbh $>25 \mathrm{~cm}$

$\mathrm{W}(32,0.6)$

Table A3.2. Sets of preference weights for different management actions and actors. Weights are additive and calculated for all individual decision units (IDU) that meet the criteria for treatable 
area. Potential fire severity is calculated for each IDU using static fire simulation (ERC, wind speed and wind direction for every IDU of $60,29 \mathrm{~km} / \mathrm{h}$ and $220^{\circ}$, respectively). Fuel model SH2, SH5, SH7 and TU5 correspond to moderate, high and very high load dry climate shrubs, and very high load dry climate timber-shrub, respectively (Scott and Burgan 2005).

\begin{tabular}{|c|c|c|c|}
\hline Landowner & Action & Where & Weight \\
\hline \multirow{26}{*}{ FEDERAL } & \multirow{10}{*}{ Thinning } & Ponderosa pine & 1100 \\
\hline & & Dry mixed conifer & 1000 \\
\hline & & Lodgepole pine & 900 \\
\hline & & Basal area greater than $20.67 \mathrm{~m} 2 / \mathrm{ha}$ & 500 \\
\hline & & Canopy cover greater than $60 \%$ & 500 \\
\hline & & Federal WUI & 500 \\
\hline & & Potential owl habitat & -100 \\
\hline & & Moist mixed conifer & -20 \\
\hline & & Potential mixed Severity Fire & 300 \\
\hline & & Potential stand replacing fire & 400 \\
\hline & \multirow{8}{*}{ Prescribed fire } & Thinning or clear cut in the previous four years & 3000 \\
\hline & & $\begin{array}{l}\text { Ponderosa pine with single layer and low canopy } \\
\text { cover }\end{array}$ & 2000 \\
\hline & & $\begin{array}{l}\text { Dry mixed conifer with single layer and low } \\
\text { canopy cover }\end{array}$ & 1000 \\
\hline & & Fuel model SH145, SHU147 or TU165 & -300 \\
\hline & & Federal WUI & -500 \\
\hline & & Potential owl habitat & -100 \\
\hline & & Moist mixed conifer & -20 \\
\hline & & Potential mixed severity fire & 100 \\
\hline & \multirow{8}{*}{ Mastication } & Federal WUI & 500 \\
\hline & & Distance to major roads less than $400 \mathrm{~m}$ & 200 \\
\hline & & Potential owl habitat & -100 \\
\hline & & Time since wildfire greater than 19 years & 100 \\
\hline & & Fuel model SH145, SHU147 or TU165 & 100 \\
\hline & & Fuel model SH142 & 50 \\
\hline & & Moist mixed conifer & -20 \\
\hline & & Potential mixed severity fire & 100 \\
\hline
\end{tabular}




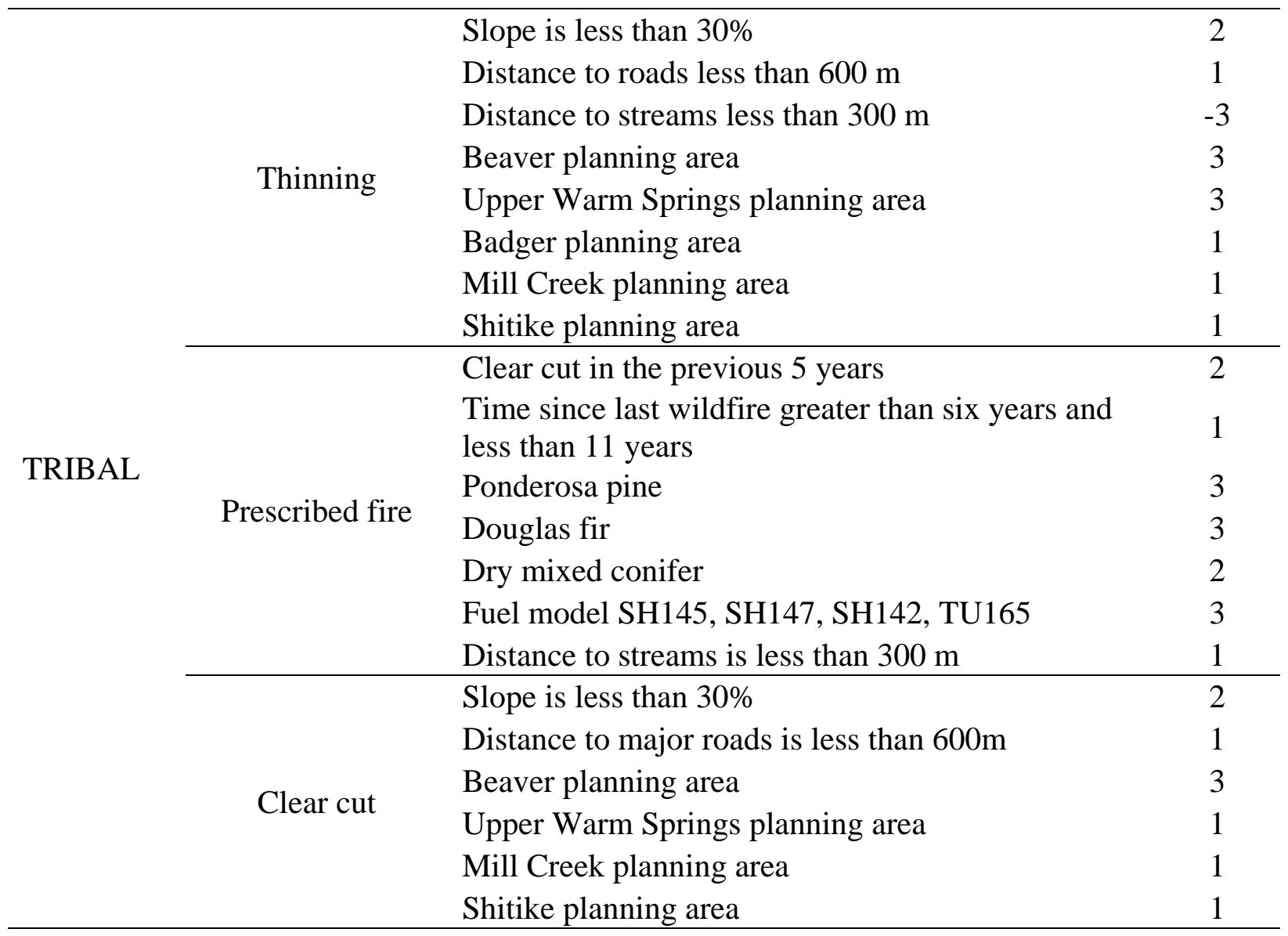

\section{LITERATURE CITED}

Scott, J. H. and R. E. Burgan. 2005. Standard fire behavior fuel models: a comprehensive set for use with Rothermel's surface fire spread model. Gen. Tech. Rep. RMRS-GTR-153, USDA Forest Service, Rocky Mountain Research Station. 
Appendix 4. Treatable area and initial conditions

Fig. A4.1. Maps of treatable area (A) and disturbance in the initial conditions landscape (B). Treatable area corresponds to areas considered suitable for forest management and are classified according to variable criteria - see methods for a description of treatable area for each landowner. Disturbances that took place between 2006 and 2011 are colored as light grey (wildfire) and dark grey (forest management). Management and wildfires in 2012 are color coded according to type of treatment and fire severity based on the Monitoring Trends Burn Severity (MTBS) dataset.
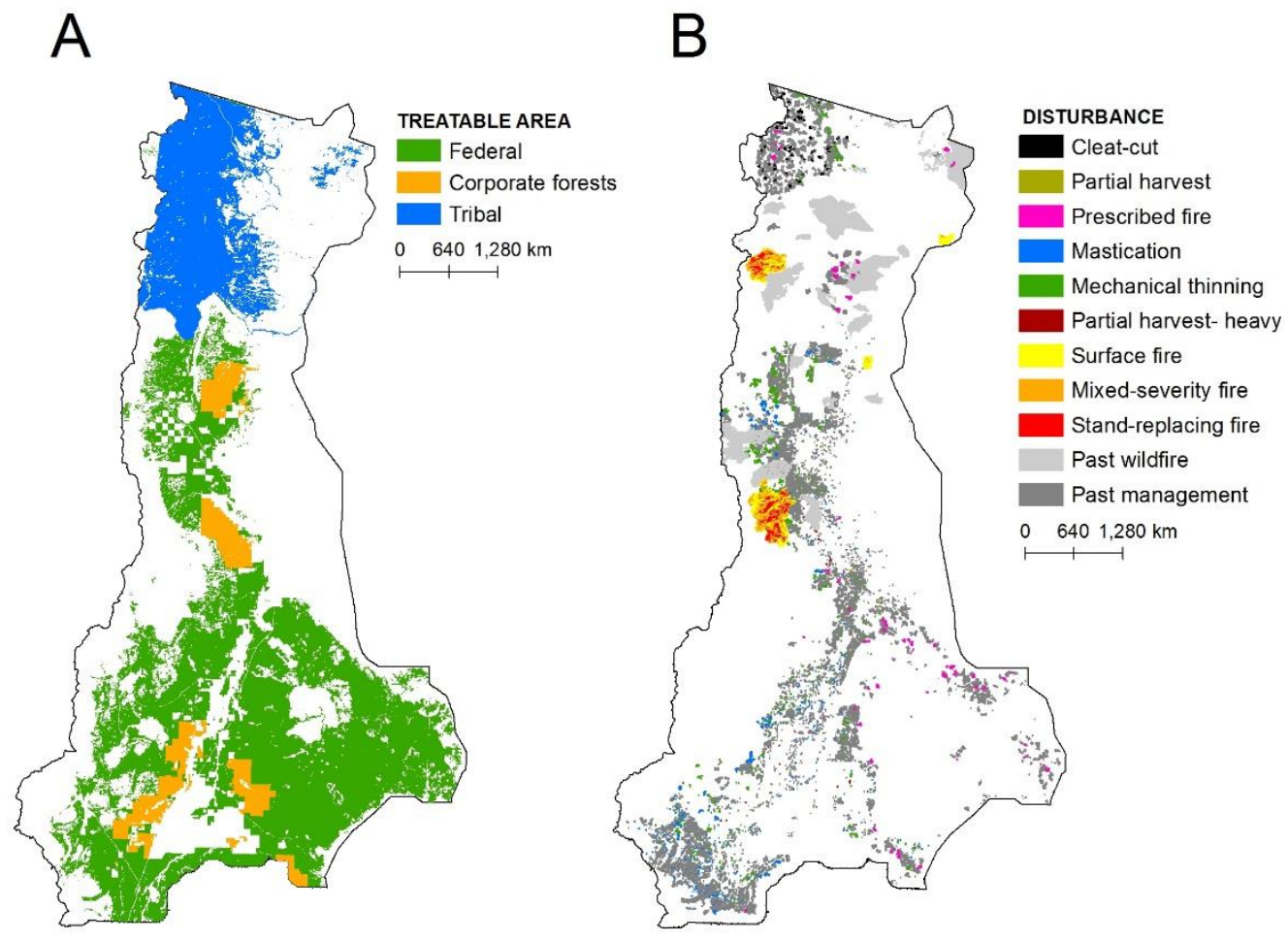
Appendix 5. Burned area analysis.

Fig. A5.1. Percentage of area burned by fire in each fire severity classe/scenario.

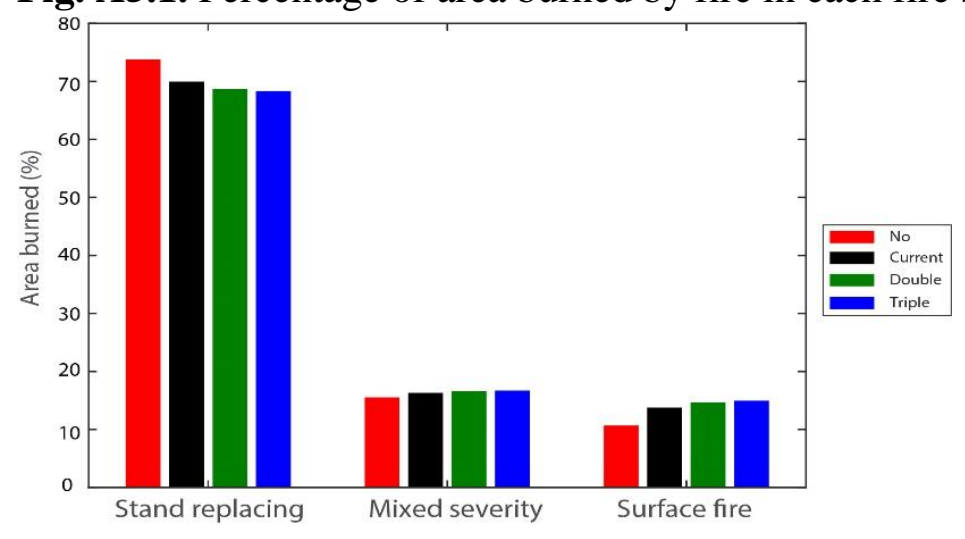

Fig. A5.2. Burned area ( $\log 10$ (hectares)) by stand-replacing (A), mixed severity (B) and surface (C) fire on all federal forested lands. i.e. Values in each year correspond to average area burned over the 15 simulation replicates and \pm one standard error (vertical bars).

A

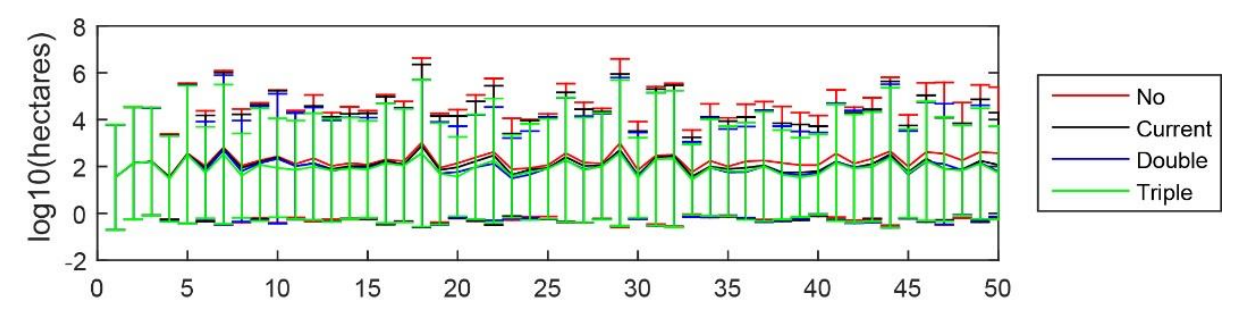

B

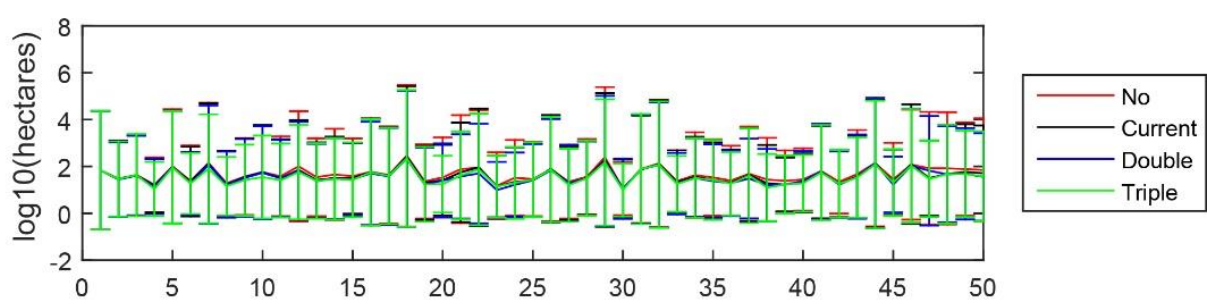

C

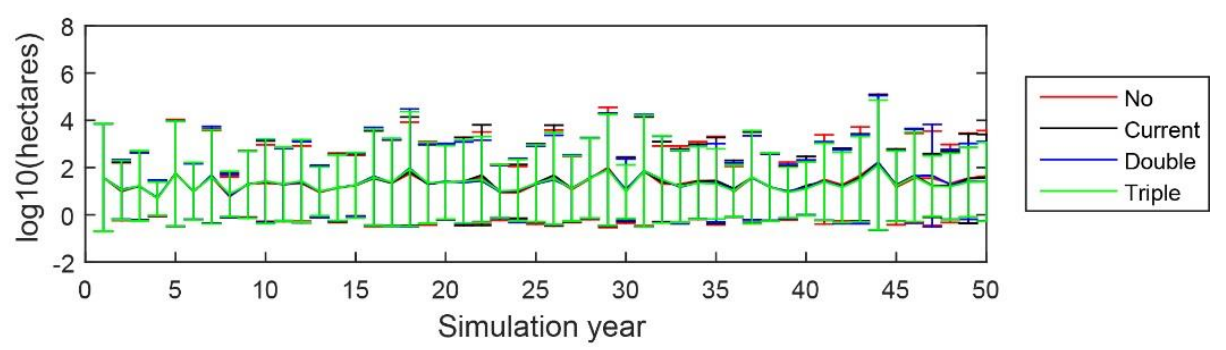


Table A5.3. Parameters (and corresponding standard error) estimated using a linear regression model with year as an explanatory variable and area burned as response variable.

\begin{tabular}{lcc}
\hline \hline & intercept & slope \\
\hline No management & $466.72 *(87.52)$ & $-0.2308(3.04)$ \\
Current management & $415.79 *(67.08)$ & $-2.3929(2.34)$ \\
Double management & $369.58^{*}(58.54)$ & $-2.0137(2.04)$ \\
Triple management & $346.46 *(56.52)$ & $-1.5696(1.97)$ \\
\hline
\end{tabular}

*Significant, $\mathrm{P}<0.05$

Table A5.4. P-values from the Kruskal-Wallis test of differences in burned area per year among all possible paired combinations of scenarios/ownership types. The null hypothesis states that data from two samples comes from the same distribution.

\begin{tabular}{lcccc}
\hline \hline Ownership/ & Scenario & Current & Double & Triple \\
\hline management & No & $0.013^{*}$ & $3.5 \times 10^{-4 *}$ & $1.4 \times 10^{-4 *}$ \\
Federal & Current & & 0.283 & 0.167 \\
& Double & & & 0.073 \\
Wilderness & No & 0.828 & 0.717 & 0.694 \\
& Current & & 0.825 & 0.831 \\
& Double & & & 0.992 \\
Old growth & No & $0.009^{*}$ & $2.4 \times 10^{-4 *}$ & $2.6 \times 10^{-5 *}$ \\
& Current & & 0.213 & 0.050 \\
& Double & & & 0.459 \\
SILVIS WUI $\dagger$ & No & 0.262 & 0.135 & 0.157 \\
& Current & & 0.619 & 0.686 \\
& Double & & & 0.904 \\
\hline
\end{tabular}

*Significantly different, $\mathrm{P}<0.05$

$†$ SILVIS Wildland Urban Interface 